\title{
Perceived Managerial and Leadership Effectiveness within the Canadian Public Sector
}

\section{R. G. Hamlin, R.G., \& S. Whitford}

\section{Abstract}

This study responds primarily to numerous calls for specific public management and public administration-related research to better understand public leadership currently performed in an increasingly complex and ambiguous world. It also responds to calls in the human resource development (HRD) literature for more qualitative managerial behavior research. The inquiry explores perceptions of what behaviorally distinguishes effective managers from ineffective managers, as expressed by managers and non-managerial employees within a Canadian public utility company. It reaches for generalization by comparing the results against findings from equivalent qualitative managerial behavior studies carried out in three subareas of the British public sector. Using the critical incident technique (CIT), concrete examples (critical incidents-CIs) of observed managerial behavior were collected from managers and non-managerial staff. The CIs $(n=530)$ were subjected to open and axial coding to identify a smaller number of discrete behavioral categories (BSs). Selective coding of the identified BSs $(n=99)$ resulted in 16 positive (effective) and 12 negative (ineffective) behavioral criteria (BCs) being deduced. Over $92 \%$ of the Canadian BSs are convergent in meaning with over $81 \%$ of the compared British BSs. Consequently, they are likely to be generalizable to other subareas of the Canadian public sector. The $8 \%$ of non-convergent Canadian BSs and their respective underpinning CIs contain no content that could be construed as being context-specific to the Canadian public utility sector. Implications of these study findings for HRD research and practice are discussed. 
PERCEIVED MANAGERIAL AND LEADERSHIP EFFECTIVENESS 


\section{PERCEIVED MANAGERIAL AND LEADERSHIP EFFECTIVENESS}

\section{INTRODUCTION}

In the increasingly complex and ambiguous world of the $21^{\text {st }}$ century new challenges and pressures are being placed on public sector organizations (Vogel \& Masal, 2015). For example, there is the need for increasing business efficiency that requires managers to be highly effective in managing upwards, downwards and outwards, and for placing less reliance on traditional hierarchical authority but instead more on the skills of negotiation, inter-organizational diplomacy, and relationship building (Head, 2010; O'Toole, Meier, \& Nicholson-Crotty, 2005). Furthermore, as Leslie and Canwell (2010) argue, the current main challenge for the public sector is to deliver improved services through a motivated and engaged workforce. This means administrative leaders/public managers need to give priority to building leadership capacity and capabilities at all levels. Their view supports Wallis and McLoughlin (2007) who contend that more effective leadership is called for at both senior and middle levels of management in public sector organizations. Such challenges have led some writers to argue that public leadership is becoming a distinctive and autonomous domain in the field of public administration/public management, and that it needs to be studied separately from general leadership (Getha Taylor et al., 2011).

This view is supported by Chapman et al. (2016) who claim there is "a lack of convergence both theoretically and empirically that presents challenges to advancing an integrative theory or even fostering a more coherent dialogue around what is known about public leadership" (p.113). Orazi, Turrini, and Valotti, (2013) assert that administrative leaders in the public sector behave differently from their counterparts in the business world. As a result, they argue there is a great need for leadership development programs to focus on these reputed behavioral differences, instead of merely mimicking programs designed for 


\section{PERCEIVED MANAGERIAL AND LEADERSHIP EFFECTIVENESS}

leaders in the private sector. However, few contemporary public sector-specific qualitative manager/leader behavior studies that focus on exploring what those behavioral differences are, or more broadly on what constitutes effective manager/leader behavioral performance in the $21^{\text {st }}$ century, have been carried out over the past two decades (Liccione, 2005; Mumford, 2011; Van Wart, 2003; 2013). Furthermore, as Vogel and Mosal (2015) state, most studies of public leadership using the "behavioural approach" are based on "conceptual foundations and with operational definitions of leadership traits, skills and behaviour" obtained from the classical literature on transformational leadership (p.1175). They also assert that "empirical evidence on whether public sector organizations facilitate or inhibit transformational leadership is sparse and yields mixed results" (p.1176). For example, Trottier, Van Wart and Wang (2008) found US federal government employees ranking their leaders higher in transactional rather than transformational competencies. Yet according to Hansen and Villadsen (2010), public managers are more likely than managers in private companies to adopt participative styles of leadership behavior which tend to fall into the transformational category of managerial competence. These mixed findings lend support for Van Wart's (2013) call for researchers to conduct behavioral studies of administrative leaders/public managers designed specifically to identify competency profiles and models that are contextspecific to public sector organizations. We suggest management training programs based on such derived profiles/models are likely to provide better guidance and support for public managers, than conventional programs informed/shaped by context-general theories such as the transformational and transactional models of leadership.

Several $21^{\text {st }}$ century human resource development (HRD) researchers have conducted manager/leader behavior studies that are consistent with the type of inquiries 


\section{PERCEIVED MANAGERIAL AND LEADERSHIP EFFECTIVENESS}

called for by Van Wart (2013). Following the example of Latham and Wexley (1977; 1994) who developed behavioral observation scales (BOS) for performance appraisal purposes using Flanagan's (1954) critical incident technique (CIT), Brown and Hanlon (2004) used CIT to create BOS for the purpose of coaching and developing entrepreneurs, identifying the training needs of prospective entrepreneurs, and for evaluating the effectiveness of entrepreneurial training programs. This involved collecting from a sample of young entrepreneurs concrete examples (i.e. critical incidents) of effective and ineffective behaviors that they had observed other entrepreneurs exhibiting. To generalize the derived BOS to other age groups and cultures, Brown and Hanlon argue that more entrepreneur behavior studies should be undertaken. More recently, Brown, McCracken and Hillier (2013) conducted a managerial behavior study using CIT to identify the 'soft (behavioral) skills' of executives that reflect the workplace dynamics within public sector organizations. They then used the results to create a BOS for application on a performance coaching program designed specifically for public executives (managers). Having empirically demonstrated the efficacy of using 'goal setting' and 'BOS techniques' to improve the transfer to practice of learned skills and knowledge, they argue that other HRD professionals should consider enhancing training transfer by creating BOS through CIT managerial behavior research and sound job analysis. Using the results of nine qualitative CIT managerial behavior studies (cases) conducted by Hamlin with various co-researchers within a diverse range of public, private, and third (not-for-profit) organizations, Hamlin and Hatton (2013) have offered a British taxonomy of perceived managerial and leadership effectiveness. This emerged from a multiple cross-case comparative analysis (MCCCA) of their obtained empirical source data. The research focus, design, methodology, method and 


\section{PERCEIVED MANAGERIAL AND LEADERSHIP EFFECTIVENESS}

protocols of their eight empirical source studies were the same. These studies were part of an expanding cumulative series of inquiries replicating the qualitative component of the other study, namely Hamlin's (1988) original CIT and factor analytic exploration of managerial effectiveness within UK secondary schools. Four of the eight 'replication' studies, together with two equivalent 'replication' managerial behavior studies that Hamlin had conducted with indigenous co-researchers in Germany and Romania respectively, have been similarly subjected to MCCCA by Patel and Hamlin (2012). This has led to the identification of an emergent European-related taxonomy of perceived managerial and leadership effectiveness. To 'test' and refine these derived taxonomies, both Hamlin and Hatton (2013) and Patel and Hamlin (2012) have called for more equivalent qualitative 'replication' managerial behavior studies to be conducted within other specific organizational settings in Non-European as well as European countries. These calls from the HRD literature are wholly consistent with those identified in the afore-mentioned public administration and public management literature.

We conclude there is a compelling need for more management researchers to explore and identify the specific types of managerial (manager/leader) behavior required to manage and lead employees effectively within contemporary public sector organizations. Our study attempts to address this need. Specifically, we report in this article the findings of an empirical qualitative study of effective and ineffective managerial behavior as manifested and observed within a Canadian public utility company. The inquiry replicates in Canada the afore-cited equivalent 'replication' managerial behavior studies carried out by Author 1 (Hamlin) with various indigenous co-researchers in several public sector organizations in the UK (cf. Hamlin \& Hatton, 2013). The core purpose was to identify the 


\section{PERCEIVED MANAGERIAL AND LEADERSHIP EFFECTIVENESS}

behavioral determinants of managerial and leadership effectiveness, as perceived by managers and non-managerial employees within the collaborating 'case study' organization. This was achieved by addressing the following central question: What behaviorally distinguishes effective managers/leaders from ineffective managers/leaders as perceived and judged by people employed within a selected Canadian public utility company, and to what extent are the findings context-specific or context general?

Consistent with Hamlin and his various co-researchers who conducted the aforecited UK-based 'replication' studies, and who followed Yukl (1989), we make no separation between the concept of 'management' and that of 'leadership' even though many theorists argue there are distinct differences. The reason for this is because 'leading' is perceived by many scholars to be an integral part of, or a complementary activity to the daily task of 'managing' (Mintzberg, 2004; Tett, Gutterman, Bleier, \& Murphy, 2000; Yukl, 2006). Thus, in the world of management practice the differences become blurred, and in many if not most organizations the two terms are used interchangeably (Bolden, 2004; Frich, Brewster, Cherlin, \& Bradley, 2015; Raelin, 2004). Consequently, throughout this article our use of the term 'managerial behavior' refers to both 'manager behavior' and 'leader behavior'. Additionally, the word leadership in our term perceived managerial and leadership effectiveness refers to the 'supervisory leadership' performed by all managers, and not to the 'strategic leadership' additionally performed by organizational leaders and top managers (House \& Aditya, 1997). Hence, the focus of our study is consistent with Van Wart's (2013) conceptualization of administrative leadership performed in public sector organizations by "people" (at all levels of management) who "lead, manage and guide government and non-profit agencies" (p.521). 
PERCEIVED MANAGERIAL AND LEADERSHIP EFFECTIVENESS

\section{LITERATURE REVIEW}

In addressing the research purpose and central question the following review of literature focuses: first on an 'historical perspective of managerial and leadership effectiveness research'; second on 'recent public sector management and administrative leadership research'; third on 'recent calls for more managerial behavior research in the public sector'; and fourth on "non-functionalist approaches to studying managerial activities and behavior'. This is followed by an outline of the specific research questions that we addressed.

\subsection{Historical perspective of managerial and leadership effectiveness research}

The most notable early inquiries that explored the 'process' component of managerial and leadership effectiveness were the Ohio State University leadership and supervisory behavior studies of Hemphill (1955), Fleishman, Harrison and Burtt (1955), and Schtreisheim and Stogdill, 1975), and also the University of Michigan managerial behavior study of Miner (1963). These were followed by: i) the CIT and factor analytic managerial behavior studies of Latham and Wexley (1977) and Latham, Fay and Saari (1979) for the purpose of developing behavioral observation scales (BOS) that could be used for appraising the performance of supervisors and first line foremen, respectively; ii) the Morse and Wagner (1978) study that led to the development of an instrument for measuring and evaluating managerial behavior associated with effective managerial performance, and iii) the early CIT and factor analytic managerial behavior studies of Hamlin who developed behavioral item questionnaires (BIQs) for identifying organization-specific behavioral dimensions (criteria) of managerial and leadership effectiveness (cf. Hamlin, 1988, Hamlin, 


\section{PERCEIVED MANAGERIAL AND LEADERSHIP EFFECTIVENESS}

2002; Hamlin, Reid \& Stewart, 1998). To our knowledge, the only subsequent qualitative managerial behavior studies that have led to the development or potential development of BIQs or BOS, other than the cumulative series of 'replication' studies conducted in the UK and other countries by Hamlin (cf. Hamlin,2009; Hamlin et al, 2013), are the previously cited studies of Brown and Hanlon (2004) and Brown, McCracken and Hillier (2013).

\subsection{Recent public sector management and administrative leadership research}

Historically, most public sector administrative leadership research has been focused on issues of reform, administrative discretion, and ethics in government, while practitioners have continued to focus their attention on debates of leaders' characteristics and leaders' actions rather than on their behavioral effectiveness (Van Wart, 2003; 2013). Furthermore, most public management/public administration studies have been focused on top managers with little attention having been given to operational managers (Cho \& Lee, 2011). From their examination of 129 studies of public services leadership conducted between 1987 and 2013, Chapman et al. (2016) found that survey instruments were the most often used method for data collection. Only 23 of the 129 studies were empirical qualitative inquiries applying qualitative data analysis methods. Furthermore, many of these qualitative studies were vague in articulating the research methods, with little detail having been given on the type of analysis undertaken.

Despite the significant increase in the number of public sector related articles devoted to administrative leadership since 2003, as reported by Van Wart (2013), we have found from our own review of the public management and public administration literature very few contemporary empirical managerial behavior studies that focus specifically on 


\section{PERCEIVED MANAGERIAL AND LEADERSHIP EFFECTIVENESS}

'managerial effectiveness', 'leadership effectiveness', or other 'managerial performancerelated' issues. Using these and other terms, including 'behavioral effectiveness', 'perceived effectiveness', 'managerial behavior' and 'leadership behavior' to search the latest 'EBSCOhost Academic Search' and 'Pro Quest Lit Search' databases, we have identified only seven articles published since 2010 of potential relevance to our study. Six of them present the findings of quantitative empirical public leadership-related research. Of these six, three explored the association between either 'transformational leadership' and 'trust' (USA: Asencio \& Mujkic, 2016), and 'motivation of public sector workers' (Sri Lanka: Gamage, 2018; USA: Wright, Moynihan, \& Pandey, 2011), and 'mission valence' (USA: Wright et al., 2011) respectively. Two explored differences in leadership behavior/style within public organizations versus private companies (Denmark: Anderson, Bjørnholt, Bro, \& Holm-Peterson, 2018; India: Joshi, Jaur, \& Jain, 2016), and one demonstrated empirically that 'perceived trustworthiness of supervisors' is positively associated with 'employee satisfaction' in public sector organizations (USA: Cho \& Lee, 2011). The qualitative study examined the relationship between 'transformational leadership' and 'public services motivation' (Denmark: Anderson et al., 2018).

The only other identified $21^{\text {st }}$ century studies relevant to our inquiry, besides the numerous qualitative 'replication' managerial behavior studies instigated and co-conducted by Hamlin and his various co-researchers in part response to Noordegraaf and Stewart's (2000) call for more managerial behavior research, are as follows. Wallis and McLoughlin (2007) explored the leadership effectiveness of senior-middle managers in the Irish public sector by measuring the frequency of observed leadership behavior; but they did not attempt to identify any specific examples of effective or ineffective behavior. In the United 


\section{PERCEIVED MANAGERIAL AND LEADERSHIP EFFECTIVENESS}

States (US), Fernandez (2008) examined the effects of leadership behavior on employee perceptions of performance and job satisfaction. He used a survey instrument based on the task-oriented and relations-oriented leadership behaviors identified by the early Ohio State Leadership Studies, plus the development-oriented leadership behaviors identified by Ekvall and Arvonen (1991) in Sweden. However, these studies say little about modern-day perceptions of those specific managerial behaviors that public managers need to emulate, or avoid exhibiting, if they are to be perceived and judged effective by their respective superiors, peers, and subordinates. Furthermore, as Fernandez (2005) laments, nearly all cases examined by researchers who have attempted to develop integrative frameworks of administrative leadership have been examples of effective managers, with virtually no attention having been given to those behaviors associated with ineffective managers. Hence, relatively little is known about the mundane everyday ineffective managerial behaviors manifested by public managers that need to be avoided.

Nevertheless, as indicated above, Hamlin with various co-researchers has conducted a cumulative series of indigenous public sector-related single organization explorations of what behaviorally distinguishes effective public managers from ineffective public managers in the UK (Hamlin, 2009); and in various non-'Anglo' countries including Egypt (Hamlin, Nassar \& Wahba, 2010), Mexico (Hamlin, Ruiz \& Wang, 2011 ) and Romania (Hamlin \& Patel, 2012). The equivalent single organization 'replication' study presented in this article extends Hamlin's line of managerial behavior research into another ‘Anglo’ country (Canada). In sharp contrast to most past managerial and leadership behavioral effectiveness studies by other researchers, it gives equal emphasis to the exploration of both effective and ineffective managerial behavior. 


\section{PERCEIVED MANAGERIAL AND LEADERSHIP EFFECTIVENESS}

\subsection{Recent calls for more managerial behavior research in the public sector}

Head (2010) argues that researchers should be focusing attention onto the specific experiences of today's managers and how they perceive and understand the skills and managerial behaviors required for strategic [and operational] success. Indeed, as Van Wart (2013) contends, based on his review of administrative leadership performed by administrative leaders/public managers- from supervisors to executives- there is a need for researchers to conduct in much greater numbers well designed studies that: (i) identify and generate "specific competency profiles" that have been "specifically designed" and are not the result of using generic "leadership survey feedback questionnaires as is common currently"; (ii) identify "models [of specific public managerial behaviors] that do a better job of providing guidance to public sector leaders [managers] on how to motivate employees discouraged by a negative environment"; (iii) explore "the differences and similarities among the sectors" because "the comparison of subareas is very shallow"; and (iv) researchers need to conduct "comparative analysis [studies] of administrative leadership similar to the Globe studies (House et al., 2004)" which means they "need to band together to develop more country-spanning studies on leadership" (p. 537).

We suggest the rationale for this call by Van Wart is reinforced by Vogel and Masal's (2015) observation that the 'behavioral approach' to studying public leadership has been guided predominantly by transformational and transactional theories of leadership. These theories, as well as other classical theories of leadership, are widely assumed to be generic and universally applicable in all organizational settings. But as Vogel and Masal 


\section{PERCEIVED MANAGERIAL AND LEADERSHIP EFFECTIVENESS}

(2015) claim, by applying such universal concepts, researchers "fail to explore the specific [behavioral] traits and dynamics of public leadership" and this has led to "very few works providing insights into the particularities of leadership in the public sector" (p. 1179). The rationale for Van Wart's call is further reinforced by: i) Chapman et al.'s (2016) claim that most studies of public leadership employ broad typologies of transformational leadership rather than [public sector] specific typologies, which means scholars are no closer to having a clearer understanding of transformational leadership in a public service context; and by ii) Van Knippenberg and Sitkin's (2013) claim that "the conceptual definition of charismatictransformational leadership is lacking", the associated "most frequently used measurement tools are invalid", and that researchers should abandon current approaches "in favor of the study of more clearly defined and empirically distinct aspects of leadership" (pp.1-2). As Vogel and Masal (2015) conclude, "much still remains to be done in order to yield urgently needed insights into the complex phenomenon of public leadership" (p.1183). Thus, with our inquiry, we have responded specifically to Van Wart's (2013) apparently well justified call for greater numbers of administrative leadership studies designed specifically to identify [behavioral] competency profiles that will do a better job of providing guidance to public sector leaders [managers] on how to motivate employees.

From an HRD perspective we suggest Van Wart's (2013) call is well-founded, particularly bearing in mind the many criticisms of extant management and leadership development (MLD) systems. As Hamlin (2010) argues, although competency frameworks have been introduced by many if not most large private and public sector organizations for the purpose of evaluating, measuring, training, and improving the managerial performance of managers, and also for managing their career progression more effectively, in many 


\section{PERCEIVED MANAGERIAL AND LEADERSHIP EFFECTIVENESS}

cases the benefits do not materialize or the competency-based frameworks and systems do not match up to expectation. Indeed, as Whiddett and Hollforde (2007) claim, many managers find it hard to use management competency frameworks. This is because they are either: i) too general and reductionist to provide enough guidance as to the specific types of managerial behavior required to be effective; or ii) they contain too many competencies with little indication given as to those specific managerial behaviors critical for success, or conversely to those that contribute to managerial failure. Furthermore, as Chapman et al. (2016) observe, drawing upon Bass (2008), Avolio, Walumbwa and Weber (2009) and Northouse (2012), the application to the public sector and public services of survey instruments (and 360 degree feedback questionnaires) that were developed to assess leadership in private organizations is still in question.

We address these concerns and criticisms by generating a body of public sector context-specific evidence that could be applied with considerable confidence by HRD practitioners and other HR professionals to inform and shape the creation of various HRrelated 'tools', including MLD programs, management competency frameworks, 360 degree feedback questionnaires, and performance appraisal criteria. We suggest such 'tools' are likely to be recognized and accepted by public managers/leaders as being more

real, and thus more relevant than HR 'tools' derived from private sector-related research or from historical context-general evidence.

\subsection{Non-functionalist approaches to the study of managerial activities and behaviour} Since the 1980s most studies of managerial activities and behavior have fallen within the functionalist paradigm (Burrell \& Morgan, 1979) using predominantly Bass and Avolio's 


\section{PERCEIVED MANAGERIAL AND LEADERSHIP EFFECTIVENESS}

(1990) multifactor leadership questionnaire (MLQ) for gathering data (cf. Chapman et al., 2016; Hinkin \& Schriesheim, 2008; Vogel \& Masal, 2015). According to Fernandez (2005), such functionalist studies have not always been feasible or successful given the variation of managerial jobs and organizational settings. Furthermore, the validity of the MLQ has been questioned because of the conceptual similarities between the core behavioral dimensions of charismatic-transformational leadership and the Ohio State initiating structure and consideration-related models (Schriesheim \& Stogdill, 1975) (cf. Scott DeRue, Nahrgang, Wellman, \& Humphrey et al., 2011; Van Knippenberg \& Sitkin 2013). For these and other limitations of the functionalist paradigm, several non-functionalist approaches have been deployed by various researchers to study the behavioral effectiveness of managers.

For example, Tsui (1990) adopted the 'multiple constituency (MC) model' for exploring managerial effectiveness at the subunit level within a collaborating organization. In this approach, effectiveness is defined as the extent to which a manager's manifested behavior and performance is congruent with his or her constituents' (i.e. superiors', peers' and subordinates') judgment of what they perceive to be effective or ineffective management or leadership within a given context. Cammock, Nilakant and Dakin (1995) adopted a 'social constructionist' approach to develop a context-specific lay model of managerial effectiveness in a large New Zealand public sector organization. For a comparative study of leadership effectiveness across a public sector and a private sector organization, Hooijberg and Choi (2001) used subjective measures of perceived effectiveness that indicated how effective managers were seen by their subordinates and superiors. Alimo-Metcalfe and AlbanMetcalfe (2001) adopted a 'grounded theory' approach and used the repertory grid technique to develop a new model of transformational leadership relevant to UK public and private 


\section{PERCEIVED MANAGERIAL AND LEADERSHIP EFFECTIVENESS}

sector organizations. For the afore-mentioned and cited cumulative series of qualitative managerial behavior studies within UK public, private and third sector organizations, Hamlin and his co-researchers adopted a 'constructivist-interpretivist' approach and used the critical incident technique (CIT) to collect their empirical data (Hamlin, 2009).

A common feature of these various non-functionalist studies is that the resulting sets of behavioral measures (dimensions/criteria) and emergent lay models were derived from people's perceptions of managerial effectiveness or leadership effectiveness which, as claimed by Lord (1985), influence managerial behavior. How managers' behaviors are observed, perceived, and judged by their respective constituencies can be important for managerial success (or failure). This is because it can determine their reputational effectiveness which has reputational consequences (Tsui, 1984). For example, a manager's behavior can "cause peers, superiors and other key people either to give or withhold important resources such as information and co-operation or lead to subordinates either following or not following their leadership.” (Hamlin, Kim, Chai, Kim \& Jeong, 2016, p. 245). Hence, we suggest HRD practitioners concerned with designing and delivering MLD programs for public managers/leaders need to use behavioral measures (dimensions/criteria) that are context-specific to the public sector in general, or to a specific subarea, or to specific organizations. This view is supported by concerns expressed about the relevance and efficacy of leadership training programs, competency-based frameworks, and 360-degree feedback questionnaires currently used to assess the effectiveness of medical (physician) and clinical (nurse) leaders within public hospitals of the British National Health Service (NHS). These concerns have led to several calls for leadership behavior research to be conducted in public healthcare-specific settings (see Gilmartin \& D’Aunno, 2007; West et al., 2015; 


\section{PERCEIVED MANAGERIAL AND LEADERSHIP EFFECTIVENESS}

Willcocks, 2012). For the above reasons, we conclude more public sector-related nonfunctionalist qualitative managerial behavior studies are warranted.

\subsection{Specific research questions addressed}

To achieve the purpose of identifying behavioral criteria of perceived managerial and leadership effectiveness within a Canadian public utility company, and to reach for empirical generalization and transferability to other specific public sector organizational settings, we addressed two specific research questions as follows::

$R Q 1$ What do contemporary managers and non-managerial employees within a selected Canadian public sector organization perceive and judge as effective and ineffective managerial behavior?

$R Q 2$ To what extant are the findings from $R Q 1$ similar or different to the findings resulting from equivalent $21^{\text {st }}$ century studies of perceived managerial and leadership effectiveness carried out within other public-sector organizations?

\section{RESEARCH METHODOLOGY}

To address $R Q 1$, our philosophical position was informed by 'pragmatism' and the pragmatic approach (Morgan, 2007). This approach allows researchers to adopt paradigmatic assumptions that best fit the purpose of the central and specific research questions of a study (Cunliffe, 2011). Consequently, we assumed a post-positivist ontology and a constructivist-interpretivist epistemology (Bryman \& Bell, 2015; Hamlin, 2015; Ponterotto, 2005). Our research design was additionally informed by Tsang and Kwan’s (1999) notion of 'empirical generalization' research based on 'replication logic', and by Eisenhardt's (1989) advocacy of ‘cross-case comparative analysis' plus Anderson's (2017) 


\section{PERCEIVED MANAGERIAL AND LEADERSHIP EFFECTIVENESS}

criteria for evaluating qualitative research. Our study is comprised of two component parts as follows:

\subsection{Component 1: Canadian 'replication' managerial behavior inquiry}

The following three sub-sections provide details of the collaborating public utility company and sample of research participants, the chosen data collection method, and the applied data analysis method.

\subsubsection{Organizational context and sample of research participants}

The collaborating organization for this component of our study is a Canadian public utility company where, at the time this research took place, Author 2 (Whitford) was employed in a senior managerial position. The company, which employs around 2,500 people, is in the business of electricity generation, transmission, and distribution. As this component of our study was replicating Hamlin's public sector-related 'replication' managerial behavior research conducted in the UK, the research design was similarly guided by the 'multiple constituency model' of organizational effectiveness as used by Tsui (1990) for exploring managerial reputational effectiveness. Hence, a purposeful sampling methodology (Creswell, 2005) was deployed to obtain a balanced sample of research participants (Baarspul \& Wilderom, 2011). The sample was comprised of managers $(n=28)$ and non-managerial employees $(n=28)$ drawn from three functionally distinct departments. All 46 had volunteered to participate in the research, and of these, 39 were male and 17 were female (see Table 1).

$<<<$ Insert Table 1 about here $>>>$ 


\section{PERCEIVED MANAGERIAL AND LEADERSHIP EFFECTIVENESS}

\subsubsection{Data collection}

Empirical data was collected solely by Author 2 using Flanagan's (1954) critical incident technique (CIT). It was applied in close accordance with the CIT protocol devised by Author 1 for his study of managerial effectiveness in UK secondary schools (Hamlin, 1988), and subsequently used for his cumulative series of managerial and leadership effectiveness studies in the UK (Hamlin, 2009). This protocol followed closely the CIT procedures that Latham and Wexley (1981) had used to develop behavioral observation scales (BOS) for increasing productivity through performance appraisal. Since the 1980s, CIT has increasingly been recognized as one of the most effective tools for obtaining data relating to managerial performance and effectiveness-related issues (Borman \& Brush, 1993), and for comparing data from different studies with the purpose of mutual confirmation and generalization of findings (Chell, 1999). Prior to starting the CIT interviews, the Canadian research participants were briefed on the interviewing protocol. This included an explanation of key terms such as 'incident', 'critical', 'critical incident', and 'effective/ineffective [managerial] performance'. The definitions adopted to explain the meaning of an 'incident' versus a 'critical incident' were obtained from Hamlin (2009), and were as follows:

"Incident: any observable human activity that is sufficiently complete in itself to permit inference and predictions to be made about the person performing the act" (p.29)

"Critical Incident: where the purpose and intent of the incident is seen to be clear and its consequences sufficiently definite to leave little doubt concerning its effect." (p.29) The definitions adopted to explain the meaning of effective performance and ineffective performance were as follows: 


\section{PERCEIVED MANAGERIAL AND LEADERSHIP EFFECTIVENESS}

"Effective Performance: is defined as behavior which you wish all subject managers to adopt, if and when faced with similar circumstances" (p. 29).

"Ineffective Performance: is defined as behavior which, if it occurred repeatedly or even once in certain circumstances, might cause you to question or doubt the managerial ability of that particular manager in that instance." (p. 30).

To elicit each critical incident during the interviews, Author 2 posed the following three standard questions as specified in the CIT protocol:

"1. What was the background situation, circumstance or context that led up to the critical incident you have in mind?"

"2. What exactly did the subject manager do or not do that [or say or not say] that was either effective or ineffective?"

"3. How was the critical incident that you have described an example of 'effective' or 'ineffective' management?’

(Hamlin, 2009, p. 31)

The duration of the CIT interviews was between 75 to 90 minutes. The respective participant interviewees were each asked to describe 4 to 5 positive and 4 to 5 negative CIs that he or she had personally observed within 12 months prior to the interview. The CIs could relate to behavior exhibited by any manager within the management hierarchy of the organization who was either above, below, or at the same level as the interviewee. The interviewees were asked not to reveal the identity of the manager whose behavior they had described. Those participants who held managerial positions were told not to volunteer CIs describing behaviors relating to their own management/leadership practices. The CIT interviews were tape-recorded with the permission of the interviewees. Author 2 transcribed the collected interview data by drafting a sentence (or at most two sentences) to 


\section{PERCEIVED MANAGERIAL AND LEADERSHIP EFFECTIVENESS}

describe the specific 'critical' aspect of the volunteered 'incidents' of effective or ineffective managerial behavior. In so doing she took great care to avoid researcher contamination creeping into the transcription process caused, for example, by the loss of vital meaning embodied within the original CIT data or by the unwitting inclusion of a change of emphasis. In the main the actual words and phraseology of the research participants who had provided the CIT data were used. Only those incidents that fully conformed with the definition of a 'critical incident-CI' were retained for further analysis.

She then subjected these retained usable CIs to 'member validation'. This involved getting the respective research participants who had volunteered the CIT data from which each specific CI had been derived, to check that the implicit and explicit meaning accurately represented what he or she had meant to convey.

\subsubsection{Data analysis}

The authors jointly subjected the retained CIs to a theoretical coding and categorizing process involving open coding and axial coding (Flick, 2009) applied at a semantic level of analysis. At the open coding stage of analytic abstraction the sentence (or sentences) of each CI was (were) scrutinised to identify the salient unit(s) of meaning and concept(s), as reflected by the key active verb(s) and phrase(s) describing it. The coded CIs seen to be identical or closely the same in textual substance and meaning with other CIs were accordingly grouped together to form discrete behavioral categories. Where a CI contained two salient units of meaning/concepts it was sorted into more than one behavioral category. Each derived category was required to contain a minimum of 3 and a maximum of 12 CIs. The reason for specifying at least 3 CIs was to avoid deducing a category that might be 


\section{PERCEIVED MANAGERIAL AND LEADERSHIP EFFECTIVENESS}

derived from the idiosyncratic behavior of a single manager within the Canadian company. By setting a maximum of 12 CIs reduced the likelihood of categories being deduced that contained two or more discrete sub-categories. Each of the deduced categories was interpreted and a label then attached. This was in the form of a brief behavioral statement (BS) describing the overarching meaning held in common with each of the respective constituent CIs.

Author 1 (Hamlin) initially subjected the derived BSs to selective coding to identify a smaller number of core categories around which they could be grouped, and by which they could be integrated (Flick, 2009). These broad categories (BCs) were interpreted, and then statements were devised to describe the essence of meaning held in common across the constituent BSs of each respective category. The BCs and their underpinning BSs were independently code-cross checked (Gibbs, 2007) by Author 2. Where discrepancies of interpretation occurred, these were reconciled through discussion until a consensus was reached. The end results of the selective coding were subjected to further code crosschecking using an external confirmatory auditor who was, and still is, an Associate Professor of Management at a US university. This doctorally qualified faculty member and active researcher is skilled in using CIT having personally conducted qualitative managerial behavior studies within several North and South American countries. Furthermore, he has had his research published in a wide range of well-respected management and HRD-related academic journals, both in the US and the UK. He was invited to provide a YES/NO response to the way each derived BS had been categorized. Where a BS appeared to him to have greater consistency of meaning with a different $\mathrm{BC}$, he indicated the alternative $\mathrm{BC}$ and explained his reasoning. He was also invited to scrutinize the proposed descriptive 


\section{PERCEIVED MANAGERIAL AND LEADERSHIP EFFECTIVENESS}

label of each BC to determine whether it fully and accurately represented the essence of the overarching meaning held in common with all the constituent BSs. In instances where this could not be confirmed, the respective BCs and descriptive labels were discussed with the confirmatory auditor to reconcile differences. Once a consensus had been reached the respective BCs and descriptive labels were re-elaborated.

\subsection{Component 2: Multiple cross-case/cross-nation comparative analysis (MCCCA).} In addressing $R Q 2$ to reach for empirical generalization of the Component 1 findings, the original intention was to explore the extent to which the BSs underpinning the deduced BCs might be similar or dissimilar to sets of BSs resulting from any equivalent contemporary public sector-related managerial behavior study carried out in Canada, and/or in the United States of America. However, because we could find no directly comparable North American-based studies, we decided to use instead one or more 'replication' managerial behavior studies carried out by Author 1 with various co-researchers within the public sector of another 'Anglo' country, namely the UK. But because all electricity generation, transmission and distribution companies are not publicly owned in the UK, and because we know of no other contemporary managerial behavior studies that have been carried out within this industry, we were unable to conduct a cross-case/cross-nation comparative analysis using studies (cases) drawn from the same subarea of the public sector of both countries. Instead, we obtained empirical source data from four studies (cases) conducted in three other subareas of the UK public sector, as follows: (i) Anglia Region of HM Customs \& Excise (Hamlin, Reidy \& Stewart, 1998) (Case UKA), (ii) an 


\section{PERCEIVED MANAGERIAL AND LEADERSHIP EFFECTIVENESS}

‘acute’ NHS Trust hospital (Hamlin, 2002) (Case UKB); (iii) Birmingham Women’s NHS Trust hospital (Hamlin \& Cooper, 2007) (Case UKC) and (v)Wolverhampton City Council Social Services Department (Hamlin \& Serventi, 2008) (Case UKD). Details of the 'subject focus', 'number of CIT informants', 'number of critical incidents (CIs) collected', 'number of effective and ineffective behavioral statements (BSs)' and overall 'number of BSs' deduced for each empirical source study are as provided in Table 2

\section{$<$ Insert Table 2 About Here $>$}

To conduct our multiple cross-case/cross-nation comparative analysis (MCCCA) we used a 'realist qualitative research' approach whereby “qualitative researchers can approach their material [data] with a view to deriving categories from it" (Madill, Jordon \& Shirley, 2000, p.4). Within a realist framework, such categories are considered "discoverable within the data", and reliability "can be assessed [qualitatively] through triangulating the findings of multiple researchers" and "in terms of consistency of meaning" (p.4). We searched at a semantic level of analysis for evidence of sameness, similarity, or at least some aspect of congruent meaning between the constituent unit(s) of meaning/concept(s), as reflected by the 'critical' active verbs and phrases constituting the descriptive labels of the compared BSs. Following Hamlin and Hatton (2013), "Sameness was deemed to exist when the sentences or phrases used to describe two or more BSs were identical or near identical. Similarity was deemed to exist when the BS sentences and/or phrases were different, but the kind of meaning was the same. Congruence existed where there was an element of sameness or similarity in the meaning of certain phrases and/or key words" (p. 373). Where such convergences of meaning were found, the respective British BSs were sorted and mapped accordingly against the corresponding Canadian BSs. The results of the 


\section{PERCEIVED MANAGERIAL AND LEADERSHIP EFFECTIVENESS}

comparative analysis were then sent to the same independent confirmatory auditor for code cross-checking. Where discrepancies of interpretation arose, these were reconciled through discussion and the coding re-elaborated after consensus was reached.

\subsection{Trustworthiness of the findings}

Assuring the accuracy and objectivity of the Component 1 findings (Knafl \& Breitmayer, 1991) was achieved through: (i) investigator triangulation (Easterby-Smith, Thorpe, \& Lowe, 1991) involving the two of us working independently of each other and at other times jointly; and (ii) the deployment of an independent confirmatory auditor who had contemporary experience and expertise of using CIT and realist qualitative analysis methods.

\section{RESULTS}

\subsection{Component 1 Results (Addressing RQ1)}

Author 2 collected a total of 530 usable critical incidents (CIs) from 56 research participants (see Table 3) of which 269 were examples of positive (effective) and 261 of negative $<<<$ Insert Table 3 about here $>>>$

(ineffective) managerial behavior. The qualitative open and axial coding of these CIs resulted in 50 positive discrete behavioral categories (BSs) and 49 negative BSs being deduced, as presented in the left-hand columns of Table 4 and Table 5 respectively. The subsequent selective coding of the derived BSs led to 16 positive broad behavioral categories (BCs) and 12 negative BCs being identified. We refer to these categories/dimensions as behavioral criteria. They are presented in bold typeface above the respective clusters of underpinning 


\section{PERCEIVED MANAGERIAL AND LEADERSHIP EFFECTIVENESS}

constituent BSs in the left-hand columns of Table 4 and Table 5 respectively. As can be noted in Table 4, three of the 50 positive BSs (P48, P49, P50) do not converge in meaning $<<<$ Insert Table 4 and Table 5 about here $>>>$

with any of the other positive BSs. Furthermore, they contain no consistency of meaning with any of the deduced positive BCs. However, they are 'near opposite' in meaning with three of the deduced negative BSs (N25, N26, N32), as also shown in Table 4. Similarly, 17 of the 49 negative BSs (N33 to N49) do not converge with any other negative BSs, and contain no consistency of meaning with any of the deduced negative BCs. However, they are 'near opposite' in meaning with one or more positive BSs, as shown in the left-hand column of Table 4. Of the 16 positive BCs, 9 are underpinned by one or more negative BSs that are 'near opposite' in meaning (see Table 4), and 3 of the 12 negative BCs are each underpinned by one 'near opposite' in meaning positive BS (see Table 5).

\subsection{Component 2 results (Addressing $R Q$ 2)}

Our multiple cross-case/cross-nation (Canada-UK) comparative analysis revealed high degrees of convergent meaning, as indicated by the way the compared British BSs are juxtaposed in the right-hand columns of Table 4 and Table 5 respectively. Due to an assumed potential word count limit, in Table 4 only one (or in some cases two) of the respective juxtaposed positive British BSs are shown in full. In Table 5, only the identification number of the negative British BSs are shown. However, to illustrate the convergence of meaning of the respective BSs underpinning the deduced BCs, and the corresponding juxtaposed British BSs, two examples are presented in Table 6.

$$
<<<\text { Insert Table } 6 \text { about here }>>>
$$

[ Full details of the Component 2 cross-case/cross-nation comparative analyses are available on request from Author 1]. 


\section{PERCEIVED MANAGERIAL AND LEADERSHIP EFFECTIVENESS}

As can be seen in Table 4, 86\% $(n=43)$ of the deduced positive Canadian BSs are the same as, or similar to, or possess an element of congruent meaning with positive BSs from one or all of the four compared British public sector studies. This is indicated by the number in the bracket posited at the end of each Canadian BS. In addition, by being 'nearopposite' in meaning to the negative Canadian BSs (N25, N26 and N32), a further 6\% $(n=3)$ of the deduced positive Canadian BSs (P48, P49 and P50) are also generalised to the British public sector. Just $8 \%(n=4)$ of the positive Canadian BSs have no apparent convergent meaning with any of the 123 compared British positive BSs, namely P21-Is willing to share power, $\mathrm{P} 29-$ Challenging employees [as part of their personal development], $\mathrm{P} 32-I$ s humble, and $\mathrm{P} 47-$ Takes control over the change process. Furthermore, only $6.12 \%(n=3)$ of the deduced Canadian negative BSs have no convergent meaning with any of the compared British negative BSs (see N4: Micromanages employees work and time; N5: Questions every decision and N11: Exhibits double standards).

\section{DISCUSSION}

In this section we summarise and discuss the results of our exploration of perceived managerial and leadership effectiveness within the Canadian public utility sector, and how they compare against what has been found in the UK. We then outline the implications of our findings for practice, discuss the study limitations, offer suggestions for future research, and close with a few concluding comments.

\subsection{Component 1 (Addressing $R Q 1$ )}

Overall, the 28 deduced positive and negative behavioral criteria (BCs) and their respective underpinning BSs provide meaningful and contextually relevant insights and a better 


\section{PERCEIVED MANAGERIAL AND LEADERSHIP EFFECTIVENESS}

understanding of what behaviorally distinguishes effective managers from ineffective managers within a Canadian public utility company. Our results suggest that $21^{\text {st }}$ century managers are perceived effective by their superiors, peers and subordinates when they: produce well informed plans and schedules of work, clearly structure staff roles, responsibilities and performance expectations; monitor and hold staff accountable against set performance criteria; provide constructive feedback; take ownership and accept responsibility when things go wrong; investigate and handle staff problems with discretion and sensitivity; show a personal interest in the work of their staff by interacting with them and parading their achievements; praise and thank staff for work well done; delegate to and empower staff; show genuine concern for their welfare and well-being; actively address their learning and personal development needs; build trusting relationships and follow through on promises and commitments; involve staff in decisions by seeking and listening to their ideas and concerns; engage in two way dialogue and hold regular meetings with staff; share information on important matters that affect them, and show and secure commitment to change initiatives, acting as champion and taking ownership of the change process. Conversely, they are perceived ineffective when they: exhibit rude, disrespectful, undermining and/or selfish/self-serving behaviour; treat staff inconsistently and with favouritism; avoid dealing with conflict/disciplinary issues; mislead and manipulate people; procrastinate, avoid making decisions and abdicate from their managerial responsibilities; make decisions based on assumptions instead of facts; and exhibit inappropriate autocratic controlling behaviour. It is likely also that managers in the Canadian public utility sector are perceived ineffective when they omit to exhibit the types of positive managerial behaviors outlined above. 


\section{PERCEIVED MANAGERIAL AND LEADERSHIP EFFECTIVENESS}

Following Cammock et al.(1995), we suggest our 16 derived positive BCs and 12 derived negative BCs could be thought of as a two-dimensional lay model of perceived managerial and leadership effectiveness relevant to the studied Canadian public utility company. A superficial comparison against Cammock et al.'s (1995) lay model of managerial effectiveness relevant to a large public sector organization in New Zealand has revealed a high degree of convergent meaning. Of the BSs underpinning the Canadian positive BCs, $74 \%(n=37)$ bear a strong similarity and consistency of meaning with one or more of the effective managerial behaviors constituting the 'conceptual' and 'interpersonal' ability scale categories constituting the New Zealand lay model.

\subsection{Component 2 (Addressing $R Q 2$ )}

Of the combined positive and negative BSs resulting from our Component 1 research, $92.93 \%(n=92)$ appear to a greater or lesser extent to be similar to the BSs resulting from the four equivalent British public sector single organization 'replication' studies against which they were compared. Conversely, of the British BSs, over $80 \%$ appear to be held in common with the derived Canadian BSs (Case UKA: 81.19\% [ $n=68$ ]; Case UKB: $85.08 \%$ [n=57]; Case UKC: $83.67 \%$ [ $n=41[$; Case UKD: $90 \%$ [n=45]). These high degrees of similarity and consistency of meaning suggest perceptions of effective and ineffective managers held by people employed within one subarea of the Canadian public sector, are much the same as those of people employed within the 'central government', 'local government' and 'healthcare' subareas of the UK public sector. It should be noted that the descriptive labels of the 7 deduced Canadian BSs (P21, P29, P32, P47, N4, N5, N11) which have no convergent meaning with any of the compared British BSs, contain no element of 


\section{PERCEIVED MANAGERIAL AND LEADERSHIP EFFECTIVENESS}

meaning that can be regarded as being context-specific or culture-specific to the Canadian public utility sector. Hence, we conclude that if a larger scale Canadian study could have been carried out, or if multiple public sector replication studies were to be carried out in Canada and likewise in the UK to reach theoretical saturation, then there is a possibility that all of the currently deduced Canadian BSs would prove to be context-general.

Interestingly, the BS findings resulting from the previously cited equivalent 'replication' studies carried out by Hamlin and other co-researchers within public hospitals in Egypt, Mexico and Romania respectively, are highly convergent in meaning with the BS findings of the two British NHS Trust hospital studies (Case UKB \& Case UKC) used for our Component 2 research. Over $92 \%$ of the positive and $90 \%$ of the negative Egyptian BSs were found to be the same, similar, or congruent in meaning with over $90 \%$ and $85 \%$ of the respective combined sets of British BSs. And over $84 \%$ of the positive and negative Mexican BSs were found to be consistent in meaning with over $82 \%$ and $90 \%$ of BSs resulting from the British UKB and UKC studies, respectively. Similarly, over $82 \%$ of the Romanian BSs were consistent in meaning with over $87 \%$ of the combined BSs resulting from the UKB and UKC studies. Hence, it can be inferred that the Canadian BS findings of our study are likely to be relevant and transferable not only to public sector organizationsincluding public hospitals-within Canada and other 'Anglo' countries, but also within culturally diverse 'Non-Anglo' countries.

\subsection{Theoretical contribution}

Component 1 of our study has generated a lay model of perceived managerial and leadership effectiveness. This has been shown to be directly convergent in meaning with 


\section{PERCEIVED MANAGERIAL AND LEADERSHIP EFFECTIVENESS}

equivalent public sector-specific lay models generated in the UK and New Zealand, and indirectly in several 'Non-Anglo' countries. Specifically, it provides contemporary insights from $21^{\text {st }}$ century research as to the types of behavior that public managers need to emulate and avoid exhibiting, if they are to be perceived effective by their superiors, peers, and subordinates. Hence, we suggest our derived public sector-related context-specific lay model is likely to strike a stronger chord with public managers than the context-general theories, concepts, and models of management and leadership generated from mid- $20^{\text {th }}$ century research. In so doing, it is likely to provide new insights and better understanding of the behavioral specificities of effective management and leadership in public sector organizations, as called for by Liccione (2005) and Vogel and Masal (2015).

Such insights on ineffective as well as effective managerial behavior are important because: (i) in any social interaction, negative events can have a stronger impact than positive events (Baumeister, Bratslavsky, Finkenauer, \& Vohs, 2001); and (ii) a constituent's reaction will depend upon the extent to which the manifested managerial behaviors match his or her expectations (Tsui, 1990). As Amabile, Schatzel, Moneta and Kramer (2004) claim, ineffective managerial behaviors might be more important in influencing the performance of a manager's subordinates and their perceptions of his or her support. Additionally, their affective negative reaction to ineffective managerial behavior may be stronger than their positive reaction to effective managerial behavior. Furthermore, cumulative low level/mundane ineffective managerial behavior may have a serious negative impact on employee satisfaction and commitment in general, which, in turn, might then impact negatively on a manager's overall performance. 


\section{PERCEIVED MANAGERIAL AND LEADERSHIP EFFECTIVENESS}

We suggest our inquiry goes some way toward addressing Van Wart's (2013) call for more research designed specifically to: (a) generate contemporary empirical evidence that can provide a basis for designing management and leadership competency profiles/frameworks more relevant to the public sector; (b) identify specific manager/leader behaviors that are perceived positively (or negatively) by employees, and thus likely to motivate (or de-motivate) them; (c) explore differences and similarities between subareas of the public sector; and to (d) conduct comparative analyses across societies with scholars banding together to develop country spanning studies.

\subsection{Implications for HRD practice}

Our study addresses Orazi et al.’s (2013) call for the creation of specific public sectorrelated leadership development programs rather than mimicking programs designed for leaders in the private sector. Their call echoes those of previous researchers who have expressed concerns and criticisms of public sector managers and their effectiveness in managing and leading within environments increasingly influenced by managerialism. For example, Boden, Cox, and Nedeva (2006) suggested there is a need for MLD programs that address effectively the 'dispiriting failure' of New Public Management. According to Collins and Holton (2004) there is wide variation in the effectiveness of MLD programs in general. Furthermore, various writers claim that many MLD training programs are ineffective, or that skills and knowledge learned are insufficiently transferred back to the manager's job (Alimo Metcalfe \& Alban Metcalfe, 2003; Brown, McCracken \& Hillier, 2013; Gurdjian, Halbeisen, \& Lane, 2014). To address these problematic shortcomings, the behavioral criteria (BCs) constituting our deduced lay model of perceived managerial and 


\section{PERCEIVED MANAGERIAL AND LEADERSHIP EFFECTIVENESS}

leadership effectiveness could be used as 'best evidence' by HRD practitioners to inform the development of 'evidence-based' MLD programs, which, we suggest, are likely to be more effective than conventional programs. Additionally, by following Brown and McCracken (2010) they could be used to create BOS to enhance the transfer of skills and knowledge learned by managers attending these MLD programs.

The findings of our study have been shown to be context-general, and not contextspecific to the Canadian public utility company that we studied. Hence, they could, though with some caution, be used by HRD/HR professionals in other public utility companies and in other subareas of the Canadian public sector, including the healthcare sector.

Furthermore, they could be used to derive behavioral measurement criteria relevant for selection, performance appraisal and other HR systems, and/or to inform 'evidence-based' HRD/OD initiatives for bringing about strategic change in the management culture of public sector organizations (e.g. Hamlin \& Reidy, 2005). Individual public managers could use the derived lay model as an assessment tool for personal improvement/selfdevelopment purposes. Those with a self-regulatory focus (Higgins, 1996; Stam, Van Knippenberg, \& Wisse, 2010) on 'promotion' and the desire to reach successes and ideals, would likely be motivated by the positive BCs constituting the model. However, those who focus on 'prevention' and the desire to avoid failures and fears of failure, would more likely be motivated by the negative BCs.

\subsection{Limitations and suggestions for future research}

We acknowledge two limitations to the study. First, the code of anonymity applied during the Component 1 CIT data collection process required that participants did not reveal the 


\section{PERCEIVED MANAGERIAL AND LEADERSHIP EFFECTIVENESS}

identity of the manager whose 'critical incident' behavior was being described. Hence, the findings from this component of our study can make no contribution to advancing a multidirectional understanding of perceived managerial and leadership effectiveness. Second, the results of our Component 1 research within the selected Canadian public utility company have been shown to be similar to those that resulted from equivalent single organization 'replication' managerial behavior studies in three different subareas of the British public sector. However, the extent to which they are generalizable and transferable to other specific organizational contexts in the Canadian public sector has yet to be demonstrated empirically.

Hence, we suggest more single organization qualitative 'replication' studies of effective and ineffective managerial behavior need to be conducted across the Canadian public utility sector, and across other subareas of the Canadian public sector. Additionally, equivalent 'replication' studies should be carried out within a wide range of Western and Non-Western countries. Furthermore, these should be followed by MCCCAs of the respective findings because country-spanning research of this kind might lead to the identification of a public sector-related 'universalistic' model or taxonomy of perceived managerial and leadership effectiveness. Such a development would accord with Chapman et al.'s (2016) call for "greater cross-pollination and confirmation research" on public leadership (p.123). It would also accord with their recommendation that scholars should "examine shared propositions across multiple studies to generate empirical findings leading to more grounded and generalizable theories of leadership" and conduct "replication studies" to provide "more comprehensive and integrated dialogue" (p.124). 


\section{PERCEIVED MANAGERIAL AND LEADERSHIP EFFECTIVENESS}

\subsection{Conclusion}

Our paper offers new and contextually relevant contemporary insights into the types of managerial behaviors that managers within a Canadian public utility company need to emulate -or avoid exhibiting- if they are to be perceived effective by their superiors, peers and subordinates. Additionally, it demonstrates empirically that managers and nonmanagerial employees in this Canadian company perceive effective and ineffective managerial behavior in much the same way as their counterparts within other organizations in different subareas of the public sector in the UK and New Zealand, and indirectly in several Non-Anglo countries. This suggests the findings of our study might have relevance and utility for informing HRD policy and practice within a wider range of public sector organizations within other subareas of the public sector, and in other countries. 
PERCEIVED MANAGERIAL AND LEADERSHIP EFFECTIVENESS

\section{REFERENCES}

Asencio, H., \& Mujkic, E. (2016). Leadership behaviors and trust in leaders: Evidence from the U.S. Federal Government. Public Administration Quarterly, Spring, 2016, 156-179. ISS 9734-9149

Alimo-Metcalfe, B., \& Alban-Metcalfe, R.J. (2001). The development of a New Transformational Leadership Questionnaire. Journal of Occupational and Organizational Psychology, 4(1), 1-23. https://doi.org/10.1348/096317901167208

Alimo Metcalfe, B., \& Alban Metcalfe, R.J. (2003). Stamp of greatness. Health Service Journal, 113(5861), 28-32. PMID: 12870328

Amabile, T. M., Schatzel, E. A., Moneta, B., \& Kramer, S. J. (2004). Leader behaviors and work environment for creativity: Perceived leader support. The Leadership Quarterly, 15, 5-32. https://doi.org/10.1016/j.leaqua.2003.12.003

Anderson, V. (2017). Criteria for evaluating qualitative research. Human Resource Development Quarterly, 28(2), 125-133. doi:10.1002/hrdq

Anderson, L.B., Bjørnholt, B., Bro,L.L., \& Holm-Peterson, C. (2018). Leadership and motivation: A qualitative study of transformational leadership and public service motivation. International Review of Administrative Sciences, 84(4), 675-691. https://doi.org/10.1177/00208552316654747

Avolio, B.J., Walumbwa, F.O., \& Weber, T. J. (2009). Leadership: Current theories, research and future directions. Annual Review of Psychology, 60, 421-29. https://doi.org/10.1146/annurev.psych.60.110707.163621 


\section{PERCEIVED MANAGERIAL AND LEADERSHIP EFFECTIVENESS}

Baarspul, H. C., \& Wilderom, C. P. M. (2011). Do employees behave differently in public-versus-private sector organizations?: A state-of-the-art review. Public Management Review, 13(7), 967-1002. https://doi.org/10.1080/14719037.2011.589614

Bass, B.M. (2008). The Bass handbook of leadership: Theory, research and managerial Applications (4 ${ }^{\text {th }}$ Ed.). New York: Free Press.

Bass, B. M., \& Avolio B. J. (1990). Multifactor leadership questionnaire. Palo Alto, CA: Consulting Psychologists Press

Baumeister, R. F., Bratslavxky, E., Finkenauer, C., \& Vohs, E. (2001). Bad is stronger than good. Review of General Psychology, 5(4), 323-370. https://doi.org/10.1037/1089-2680.5.4.323

Boden, R., Cox, D., \& Nedeva, M. (2006). The appliance of science?: New public management and strategic change. Technology Analysis \& Strategic Management, 18(2), 125-141. https://doi.org/10.1080/09537320600623941

Bolden, R. (2004). What is leadership? Leadership south west research report. Exeter, UK: South West of England Regional Development Agency.

Borman, W. C., \& Brush, D. H. (1993). More progress toward a taxonomy of managerial performance requirements. Human Performance, 6(1), 1-21. https://doi.org/10.1207/s15327043hup0601_1

Brown, T. C., \& Hanlon, D. (2004). Developing behavioral observation scales to foster effective entrepreneurship. Journal of Small Business and Entrepreneurship, 17(2) 103-117. https://doi.org/10.1080/08276331.2004.10593315. 


\section{PERCEIVED MANAGERIAL AND LEADERSHIP EFFECTIVENESS}

Brown,T. C., McCracken, M., \& Hillier, T-L. (2013). Using evidence-based practices to enhance transfer of training: Assessing the effectiveness of goal setting and behavioural observation scales. Human Resource Development International, 16(4), 374-389. http://dx. doi.org/10.1080/13678868.2013.812291

Bryman, A., \& Bell, E. (2015). Business research methods (4 ${ }^{\text {th }}$ ed.) Oxford, UK: Oxford University Press,

Burrell, G., \& Morgan, G. (1979) Sociological paradigms and organisational analysis. Aldershot, UK: Gower,

Cammock, P., Nilakant, V., \& Dakin, S. (1995). Developing a lay model of managerial Effectiveness. Journal of Management Studies, 32(4), 443-474. https://doi.org/10.1111/j.1467-6486.1995.tb00784x

Chapman, C., Getha-Taylor, H., Holmes, M. H., Jacobson, W. S., Morse, R. S., \& Sowa, J. E. (2016). How public service leadership is studied: An examination of a quarter century of scholarship. Public Administration, (94)1, 111-128.

doi: 10.1111/padm.12199

Chell, E. (1999). Critical incident technique. In G. Symon \& C. Cassell (Eds.), Qualitative methods and analysis in organizational research: A practical guide. London, UK: Sage.

Cho, Y. J., \& Lee, J. W. (2011). Perceived trustworthiness of supervisors, employee satisfaction and cooperation. Public Management Review, 13(7), 941-965. https://doi.org/10.1080/14719037.2011.589610 


\section{PERCEIVED MANAGERIAL AND LEADERSHIP EFFECTIVENESS}

Collins, D. B., \& Holton, E. F. (2004). The effectiveness of managerial leadership development programs: A meta-analysis of studies from 1982 to 2001 . Human Resource Development Quarterly, 15(2), 217-248. https://doi.org/10.1002/hrdq.1099

Creswell, J. W. (2005). Educational research: Planning, conducting, and evaluating quantitative and qualitative research ( $2^{\text {nd }}$ ed.). Upper Saddle River, NJ: Merrill Prentice Hall,

Cunliffe, A. L. (2011). Crafting qualitative research: Morgan and Smircich 30 years on. Organizational Research Methods, 14 (4), 647-673. https://doi.org/ 10.1177/1094428110373658

Easterby-Smith, M., Thorpe, R., \& Lowe, A. (1991) Management research: An introduction, London, UK: Sage.

Ekvall, G., \& Arvonen, J. (1991). Change-centered leadership: An extension of the twodimensional model. Scandinavian Journal of Management, 7(1), 15-26. https://doi.org/10.1016/0956-5221(9)90024-u

Eisenhardt, K. M. (1989). Building theories from case study research. Academy of Management Review, 14, 532-550. https://doi.org/10.5465/amr.1989.4308385

Fernandez, S. (2005). Developing and testing an integrative framework of public sector leadership: Evidence from the public education arena. Journal of Public Administration Research and Theory, 15(2), 197-217. https://doi.org/10.1093/jopart/mu.014 


\section{PERCEIVED MANAGERIAL AND LEADERSHIP EFFECTIVENESS}

Fernandez, S. (2008). Examining the effects of leadership behavior on employee perceptions of performance and job satisfaction. Public Performance \& Management Review, 32(2), 197-217. https://doi.org/1-.2753/PMR15309576320201

Flanagan, J. (1954). The critical incident technique. Psychological Bulletin, 51(4), 327-358.

Fleishmann E. A., Harris, E. F., \& Burtt, H. F. (1955). Leadership and supervision in industry. Columbus, OH: Ohio State University.

Flick, U. (2009). An introduction to qualitative research (4 ${ }^{\text {th }} \mathrm{ed}$.), London, UK: Sage.

Frich, J. C., Brewster, A. L., Cherlin, E. J., \& Bradley, E. H. (2015). Leadership development programs for physicians: A systematic review. Journal of General Internal Medicine, 30(5), 656-674. https://doi.org/10.1007/s11606-014-3141-1h

Gamage, C. C. (2018). Effects of leadership on motivating public sector technology workers. International Journal of Scientific \& Technology Research, (7)8, 181-188 ISSN 2277-8616 181 IJSTR@2018 www.ijstr.org

Gibbs, G. (2007). Analyzing qualitative data: The Sage qualitative research kit. London, UK: Sage,

Gilmartin, M. J., \& D’Aunno, T. A. (2007). Leadership research in healthcare: A review and roadmap. The Academy of Management Annals, 1(1), 387-438.

Getha-Taylor, H., Holmes, M.H., Jacobson, W.S., Morse, R. S., \& J.E. Sowa, J.E. (2011) Focusing the public leadership lens: Research propositions and questions in the Minnowbrook tradition. Journal of Public Administration Research and Theory, (21)1, 83-97. https://doi.org/10.2307/40961921 


\section{PERCEIVED MANAGERIAL AND LEADERSHIP EFFECTIVENESS}

Gurdjian, P., Halbeisen, T.. \& Lane, K. (2014). Why leadership-development programs fail. McKinsey Quarterly, January, 1-9.

Hamlin, R. G. (1988) The criteria of managerial effectiveness in secondary schools. Published MPhil thesis CORE: Collected and Original Resources in Education, The International Journal of Educational Research in Mircofiche, 12(1), 1-221

Hamlin, R. G. (2002). A study and comparative analysis of managerial and leadership effectiveness in the National Health Service: an empirical factor analytic study within an NHS Trust Hospital. Health Services Management Research ,15, 1-20.

Hamlin, R. G. (2009) Universalistic models of managerial and leadership effectiveness. Saarbrucken:VDM Verlag Publishing

Hamlin, R.G. (2010). Evidence-based leadership and management development. In J. Gold, R. Thorpe \& A. Mumford (Eds.) Gower handbook of leadership and management development, (pp. 197-220) Farnham: Abingdon,UK: Gower.

Hamlin, R (Bob). G. (2015). Paradigms, philosophical prisms and pragmatism in HRD research. In M. N. K. Saunders \& P. Tosey (Eds.), Handbook of research methods on human resource development (pp.13-31). Cheltenham, UK: Edward Elgar Publishing Ltd

Hamlin, R. G. \& Cooper, D. J. (2007) Developing effective managers and leaders within healthcare and social care contexts: An evidence-based approach. In: S. Sambrook \& J. Stewart (Eds.), HRD in the public sector: the case of health and social care (pp.187-212). London: Routledge. 


\section{PERCEIVED MANAGERIAL AND LEADERSHIP EFFECTIVENESS}

Hamlin, R. G., \& Hatton, A. (2013). Toward a British taxonomy of perceived managerial and leadership effectiveness. Human Resource Development Quarterly, 24(3), 365406. doi: $10.1002 /$ hrdq. 21163

Hamlin, R. G., Kim, S., Chai, D-S, Kim, J., \& Jeong, S. (2016). Perceived managerial and leadership effectiveness within South Korean and British private companies: A derived etic comparative study. Human Resource Development Quarterly, 27(2), 237-269. doi: 10.1002/hrdq.21253

Hamlin, R.G., Nassar, M., \& Wahba, K. (2010). Behavioural criteria of managerial and leadership effectiveness within Egyptian and British public sector hospitals: An empirical study and multiple-case/cross-nation comparative analysis. Human Resource Development International, 13(1), 43-64. doi:10.1080/13678861003608238

Hamlin, R. G. \& Patel, T (2012). Behavioural indicators of perceived managerial and leadership effectiveness in Romanian and British public sector hospitals. European Journal of Training and Development, 36(2/3), 234-261.

doi:10.1108/03090591211204733

Hamlin, R. G. \& Reidy, M. (2005) Facilitating organizational change and development through professional researcher-practitioner partnerships. ASTD International conference \& exposition, Orlando, Florida, USA, June. 


\section{PERCEIVED MANAGERIAL AND LEADERSHIP EFFECTIVENESS}

Hamlin, R. G., Reidy, M. \& Stewart, J. (1998) Bridging the HRD research-practice gap through professional partnership Human Resource Development International, 1(3), 273-290. https://doi.org/10.1080/13678869800000038

Hamlin, R.G., Ruiz, R. \& Wang, J. (2011). Perceived managerial and leadership effectiveness within Mexican and British public sector hospitals: An empirical study and cross-nation comparative analysis. Human Resource Development Quarterly, 22(4), 491-517. doi:10.1002/hrdq.20087

Hamlin, R.G. \& Serventi, S. (2008). Generic behavioural criteria of managerial effectiveness: An empirical and comparative study of UK local government. Journal of European Industrial Training, 32(4), 285-302.

g doi: 10.1108/03090590810871388

Hansen, J. R. \& Villadsen, A. R. (2010). Comparing public and private managers' leadership styles: Understanding the role of job context. International Public Management Journal, 13(3), 247-274. https://doi.org/10.1080/10967494.2010.503793

Head, B. W. (2010). Public management research: Towards relevance. Public Management Review, 12(5), 571-585. https://doi.org/10.1080/14719031003633987

Hemphill, J. K. (1955). Leadership behavior associated with the administrative reputation of college departments. The Journal of Educational Psychology, 46(7), 385-401.

Higgins, E. T. (1996). The 'self digest': Self-knowledge serving self-regulatory functions. Journal of Personality and Social Psychology, 71, 1062-1083. 


\section{PERCEIVED MANAGERIAL AND LEADERSHIP EFFECTIVENESS}

https://doi.org/10.1037/0022-3514.71.6.1062

Hinkin, T. R., \& Schriesheim, C. (2008). A theoretical and empirical examination of the transactional and non-leadership dimensions of the Multifactor Leadership Questionnaire (MLQ) [Electronic version], available at Cornell University School of Hospitality Administration site: http://scholarship.sha.cornell.edu/articles/668

Hooijberg, R., \& Choi, J. (2001). The impact of organizational characteristics on leadership effectiveness models. Administration \& Society, 33(4), 403-431. https://doi.org/10.1077/0095399701334002

House, R. J., \& Aditya, R.N. (1997). The social scientific study of leadership: Quo vadis? Journal of Management, 23(3), 409-465. https://doi.org/10.1177/01492063902300306

House, R. J., Hanges, P. J., Javidan, M., Dorfman, P.W., \& Gupta, V. (2004). Leadership, culture, and organizations: The GLOBE study of 62 societies, London, UK: Sage Publications,

Joshi,P., Kaur, H., Jain, A. (2016). Leadership behaviour of manager: An antecedent of job satisfaction of subordinates. Journal of Indian Management, 1(4), 19-31.

Knafl, K., \& Breitmayer, B. (1991). Triangulation in qualitative research: Issues of conceptual clarity and purpose. In J Morse (Ed.), Qualitative nursing research: A contemporary dialogue (pp. 226-239). London, UK: Sage.

Latham, G.P., \& K.N. Wexley, K.N. (1994). Increasing productivity through performance appraisal. Reading, MA: Addison-Wesley. 


\section{PERCEIVED MANAGERIAL AND LEADERSHIP EFFECTIVENESS}

Latham, G. P., \& Wexley, K. N. (1977). Behavioral observation scales for performance appraisal. Personnel Psychology, 30(2), 255-268.

https://doi.org/10.1111?j.1744_6570.1977.tb02092.x

Latham, G. P., \& Wexley, K. N. (1981). Increasing productivity through performance appraisal. Reading, MA: Addison-Wesley.

Latham, G. P., Fay, C.H., \& Saari, L. M. (1979). The development of behavioral observation scales for appraising the performance of foremen. Personnel Psychology, 32, 299-311. https://doi.org/10.1111/j.1744_6570.1979.tb02136.x

Leslie, K., \& Canwell, A. (2010). Leadership at all levels: Leading public sector organisations in an age of austerity. European Management Journal, 28(4), 297-305. https://doi.org/10.1016/j.emj.2010.05.006

Liccione, W. J. (2005). Balanced management: A key component of managerial effectiveness. Performance Improvement, 44(2), 32-38. https://doi.org/10.1002/pfi.4140440209

Lord, R. G. (1985). An information processing approach to social perceptions, leadership and behavioral measurement in organizations. Research in Organizational Behavior, 7, 87-128.

Madill, A., Jordon, A. , \& Shirley, C. (2000). Objectivity and reliability in qualitative analysis: Realist, contextualist and radical constructionist epistemologies. British Journal of Psychology, 91,(1) 1-20. https://doi.org/10.1348/000712600161646

Mintzberg, H. (2004). Managers not MBAs: A hard Look at the soft practice of managing and management development. San Francisco, CA: Berrett-Koehler: 


\section{PERCEIVED MANAGERIAL AND LEADERSHIP EFFECTIVENESS}

Morgan, D. L. (2007). Paradigms lost and pragmatism regained: Methodological implications of combining qualitative and quantitative methods. Journal of Mixed Methods Research, 1(1), 48 -76. https://doi.org/10.1177/234568906292462

Morse, J. J., \& Wagner, F. R.(1978). Measuring the process of managerial effectiveness. Academy of Management Journal, 21(1), 23-35.

Mumford, D. M. (2011). A hale farewell: The state of leadership research. The Leadership Quarterly, 22(1), 1-7. https://doi.org/10.1016/j.leaqua.2010.001

Noordegraaf, M., \& Stewart, R. (2000). Managerial behaviour research in private and public sectors: Distinctiveness, disputes, and directions. Journal of Management Studies, 37(3), 427-443. https://doi.org/10.111/1467-6486.00187

Northouse, P.G. 2012. Leadership: Theory and practice, $\left(6^{\text {th }}\right.$ ed.). Thousand Oaks, CA: Sage.

Orazi, D. C., Turrini, A., \& Valotti, G. (2013). Public sector leadership: new perspectives for research and practice. International Review of Administrative Sciences, 79(3) 486-504. https://doi: 10.1177/0020852313489945

O’Toole, L. J., Meier, K. J., \& Nicholson-Crotty, S. (2005). Managing upward, downward and outward. Public Management Review, 7(1), 45-68. https://doi.org/10.1080/1471903042000339419

Ponterotto, J. (2005). Qualitative research in counseling psychology: A primer on research paradigms and philosophy of science. Journal of Counseling Psychology, 52, 126-136. https://doi.org/10.1037/0022-0167.52.2.126

Raelin, J. (2004). Don't bother putting leadership into people. Academy of Management Executive, 18 (3), 340-355. https://www.jstor.org/stable/4166102 


\section{PERCEIVED MANAGERIAL AND LEADERSHIP EFFECTIVENESS}

Schriesheim, C. A., \& Stogdill, R. M. (1975). Differences in factor structure across three versions of the Ohio State Leadership Scales. Personnel Psychology, 28, 189-206. https://doi.org/10.1111/j.1744_6570.1975.tb01380.x

Scott DeRue, D., Nahrgang, J. D., Wellman, N., \& Humphrey, S. E. (2011). Trait and behavioral theories of leadership: A integration and meta-analytic test of their relative validity. Personnel Psychology, 64, 7-52. https://doi.org/10.111/j.1744-6570.2010.01201.x

Stam, D. A., Van Knippenberg, D., \& Wisse, B. (2010). The role of regulatory fit in visionary leadership. Journal of Organizational Behavior, 31(4) 499-518. https://www.jstor.org/stable/41683926

Tett, R. P., Gutterman, H. A., Bleier, A., \& Murphy, P. J. (2000). Development and content validation of a "hyperdimensional" taxonomy of managerial competence, Human Performance, 13, 205-251. https://doi.org/10.1207/S15327043HUP1303_1

Trottier, T., Van Wart, M., \& Wang, X. (2008). Examining the nature and significance if leadership in government organizations. Public Administration Review, 68(2), 319-333. https://doi.org/10.1111/j.1540_6210.2007.00865.x

Tsang, E. K. K., \& Kwan, K.-M. (1999). Replication and theory development in organizational science: A critical realist perspective. Academy of Management Review, 24(4), 759-780. https://doi.org/10.5465/amr.1999.2553252

Tsui, A.S. (1984). A role set analysis of managerial reputation. Organizational Behavior and Human Performance, 34, 64-96. https://doi.org/10.1016/0030-5073(84)90037.0 


\section{PERCEIVED MANAGERIAL AND LEADERSHIP EFFECTIVENESS}

Tsui, A. S. (1990). A multiple-constituency model of effectiveness: An empirical examination at the human resource subunit level. Administrative Science Quarterly, $35,458-483$.

Van Knippenberg, D., \& Sitkin, S. B. (2013). A critical assessment of charismatictransformational leadership research: Back to the drawing board? The Academy of Management Annals, 7(1), 1-60.

Van Wart, M. (2003). Public-sector leadership theory: an assessment. Public Administration Review, 63(2), 214-228. https://doi.org/10.1111/1540-6210.00281

Van Wart, M. (2013). Administrative leadership theory: A reassessment after 10 years. Public Administration, 91(3), 521-543. https://doi.org/10.1111/padm.12017

Vogel, R., \& Masal, D. (2015). Public leadership: A review of the literature and framework for future research. Public Management Review, (17)8, 1165-1189, doi.org/10.1080/14719037.2014.895031

Wallis, J., \& McLoughlin, L. (2007). A diagnosis of leadership effectiveness in the Irish public sector. Public Management Review, 9( 3), 327-351. https://doi.org/10.1080/14719030701425670

West M., Armit, K., Loewenthal, L., Eckert, R., West, T., \& Lee, A. (2015). Leadership and leadership development in healthcare: The evidence base. London, UK: Faculty of Medical Leadership and Management.

Willcocks, S. G. (2012). Exploring leadership effectiveness: Nurses as clinical leaders in the NHS. Leadership in Health Services, 25(1), 8-19. ISSN:1751-1879

Whiddett, S., \& Hollyforde, S. (2007) Competencies toolkit. London, UK: Chartered Institute of Personnel and Development. 


\section{PERCEIVED MANAGERIAL AND LEADERSHIP EFFECTIVENESS}

Wright, B.E., Moynihan, D. P., \& Pandey, S. K. (2011). Pulling the levers:

Transformational leadership, public service motivation, and mission valence. Public Administration Review, (72)2, 206-215. doi: 10.111/j.1540-6210.2011.02496.x

Yukl, G. (1989). Managerial leadership: A review of theory and practice. Journal of Management, 15(2), 251-289. https://doi.org/10.1177/014920638901500207

Yukl, G. (2006). Leadership in organizations. (6 $6^{\text {th }}$ ed.). Upper Saddle River, NJ: Pearson. 


\section{PERCEIVED MANAGERIAL AND LEADERSHIP EFFECTIVENESS}

Table 1.

Component 1 Empirical Source Study: Sample of Participants

\begin{tabular}{lccccc}
\hline Locations & Total & Male & Female & Managers & $\begin{array}{c}\text { Non-Managerial } \\
\text { Employees }\end{array}$ \\
\hline Plant & 20 & 19 & 1 & 11 & 9 \\
\hline Field & 18 & 16 & 2 & 10 & 8 \\
\hline $\begin{array}{l}\text { Head } \\
\text { Office }\end{array}$ & 18 & 4 & 14 & 7 & 11 \\
\hline & 56 & 39 & 17 & 28 & 28 \\
\hline
\end{tabular}

Table 2.

Obtained empirical source data used for Component 2 of the study

\begin{tabular}{|c|c|c|c|c|c|c|}
\hline $\begin{array}{l}\text { The four British emic studies } \\
\text { of perceived managerial and } \\
\text { leadership effectiveness }\end{array}$ & $\begin{array}{l}\text { Subject } \\
\text { focus of } \\
\text { the study* }\end{array}$ & $\begin{array}{l}\text { No. of } \\
\text { CIT } \\
\text { informants }\end{array}$ & $\begin{array}{l}\text { No. of } \\
\text { CIs } \\
\text { collected } \\
\end{array}$ & $\begin{array}{l}\text { No. of } \\
\text { effective } \\
\text { BSs }\end{array}$ & $\begin{array}{l}\text { No. of } \\
\text { ineffective } \\
\text { BSs }\end{array}$ & $\begin{array}{l}\text { Total } \\
\text { number } \\
\text { of BSs }\end{array}$ \\
\hline \multicolumn{7}{|l|}{ Public Sector Organizations } \\
\hline $\begin{array}{l}\text { Case UKA a department of } \\
\text { the British Civil Service } \\
\text { Hamlin, Reidy \& Stewart } \\
\text { (1998) }\end{array}$ & S, M \& FL & 130 & 1,200 & 43 & 40 & 83 \\
\hline $\begin{array}{l}\text { Case UKB - an 'acute' NHS } \\
\text { Trust hospital } \\
\text { Hamlin (2002) }\end{array}$ & $\begin{array}{ll}\text { S, M. \& } \\
\text { FL }\end{array}$ & 57 & 405 & 30 & 37 & 67 \\
\hline $\begin{array}{l}\text { Case UKC- Birmingham } \\
\text { Women's NHS Trust hospital } \\
\text { Hamlin \& Cooper (2007) }\end{array}$ & $\mathrm{S}, \mathrm{M} \& \mathrm{FL}$ & 60 & 467 & 25 & 24 & 49 \\
\hline $\begin{array}{l}\text { Case UKD-W'ton City } \\
\text { Council Social Services Dept. } \\
\text { Hamlin \& Serventi (2008) }\end{array}$ & M \& FL & 40 & 218 & 34 & 25 & 59 \\
\hline
\end{tabular}

Note: $* \mathrm{~S}=$ Senior managers; $\mathrm{M}=$ Middle managers; $\mathrm{FL}=$ First line managers

Table 3.

Component 1 Empirical Source Study: Collected Critical Incidents- CIs

\begin{tabular}{lccccc}
\hline & $\begin{array}{c}\text { Critical } \\
\text { Incidents } \\
\text { from } \\
\text { Interviews }\end{array}$ & $\begin{array}{c}\text { Effective } \\
\text { Managerial } \\
\text { Behaviours }\end{array}$ & $\begin{array}{c}\text { Ineffective } \\
\text { Managerial } \\
\text { Behaviours }\end{array}$ & $\begin{array}{c}\text { Total } \\
\text { Critical } \\
\text { Incidents } \\
\text { Excluded }\end{array}$ & $\begin{array}{c}\text { Total } \\
\text { Crable } \\
\text { Critical } \\
\text { Incidents }\end{array}$ \\
\hline Plant & 241 & 100 & 95 & 46 & 195 \\
Field & 190 & 86 & 82 & 22 & 168 \\
Head & & 83 & 84 & 54 & 167 \\
Office & 221 & 269 & 261 & 122 & 530 \\
\cline { 2 - 6 } Totals & 652 & 269 & & & \\
\hline
\end{tabular}




\section{PERCEIVED MANAGERIAL AND LEADERSHIP EFFECTIVENESS}

Table 4.

Deduced Positive Canadian Public Utility BCs with Underpinning BSs and Comparison Against Convergent British Public Sector Positive BSs

\begin{tabular}{|c|c|}
\hline $\begin{array}{c}\text { Canadian Public Utility Study } \\
\text { Deduced Positive Behavioral Criteria } \\
\text { Underpinning positive BSs and near opposite in } \\
\text { meaning negative BSs }\end{array}$ & $\begin{array}{l}\text { British Public Sector Studies } \\
\text { UKA: HM Customs \& Excise -Anglia Region }(\mathrm{n}=43 \mathrm{BSs}) \\
\text { UKB: An Acute NHS Trust Hospital }(\mathrm{n}=30 \mathrm{BSs}) \\
\text { UKC: Birmingham Women's NHS Trust Hospital ( } \mathrm{n}=25 \mathrm{BSs}) \\
\text { UKD: W'ton City Council Social Services Dept. ( } \mathrm{n}=34 \mathrm{BSs}) \\
\text { Convergent positive BSs and near opposite in } \\
\text { meaning negative BSs } \\
\end{array}$ \\
\hline \multicolumn{2}{|l|}{$\begin{array}{l}\text { 1) Well informed planning and scheduling of work, and } \\
\text { structuring of staff roles, responsibilities and performance } \\
\text { expectations }\end{array}$} \\
\hline $\begin{array}{l}\text { P1) Displays effective work management through planning, } \\
\text { scheduling (4) } \\
\text { P2) Provides structure by setting expectations, roles, } \\
\text { responsibilities and timelines, [and resources] (2) } \\
\text { P3) Providing structure through the learning process (2) } \\
\text { P4) Considers all input [from other people and sources } \\
\text { when planning/scheduling] (3) } \\
\text { Near Opposite Negative BSs } \\
\text { N45) Does not plan, schedule, and prioritize well, } \\
\text { N46) Fire fights rather than plans for the future } \\
\text { N47) Displays poor organization and focus } \\
\text { N49) Provides no structure for or expectations }\end{array}$ & $\begin{array}{l}\text { UKA: P1) Actively seeks to ensure staff have the necessary } \\
\text { resources for the job, including operational equipment, adequate } \\
\text { staffing, technical support and any data or sets of guidelines } \\
\text { required; P2; N27 } \\
\text { UKB: P29) Thinks ahead and ensures things are done in good } \\
\text { time, prepares well for situations and contingencies (e.g. uses } \\
\text { good forward planning, prepares well for negotiations, is forward } \\
\text { thinking); P5; P14; P20; P28; N15; N30; N31 } \\
\text { UKC: P10; P9. } \\
\text { UKD: P2. Gathers all the relevant facts and data to make } \\
\text { informed decisions. P5; P13; N } 14 ; N 22\end{array}$ \\
\hline \multicolumn{2}{|l|}{$\begin{array}{l}\text { 2) Evaluating staff requests [for help/support] based on } \\
\text { need, and accommodating them }\end{array}$} \\
\hline $\begin{array}{l}\text { P5) Evaluates requests [for help/support] based on need and } \\
\text { the whole picture (2) } \\
\text { P6) Accommodating their needs [requests of staff] (3) } \\
\text { Near Opposite Negative BS } \\
\text { N34) Provides no support with other groups. }\end{array}$ & $\begin{array}{l}\text { UKA: P20) Gives technical advice to, instils confidence in, and } \\
\text { acts as a sounding board for staff who find themselves having to } \\
\text { deal with complex work for which they need help and support; } \\
\text { P25. } \\
\text { UKB: N19 } \\
\text { UKC: P 23; P22; N6 N2, N14. }\end{array}$ \\
\hline
\end{tabular}

\section{3) Taking ownership/accepting responsibility when things go wrong, and/or holding staff and team accountable by monitoring their performance against set criteria and providing constructive feedback.}

P7) Holds others [i.e. staff] accountable [for their behavior/performance] (2)

P8) Taking ownership and accepting responsibility; stands up to the plate (1)

P9) Provides feedback against project criteria (2)

P10) Follows up on issues providing constructive feedback (3)

P11) Provides measurement criteria and follow up (1)

UKA: P1) Actively seeks to ensure staff have the necessary staffing, technical support and any data or sets of guidelines required; $\mathrm{P} 2 ; N 27$

UKB: P29) Thinks ahead and ensures things are done in good ime, prepares well for situations and contingencies (e.g. uses forward planning, prepares well for negotiations, is forwar

UKC: P10; P9.

UKD: P2. Gathers all the relevant facts and data to make informed decisions. P5; P13; $N$ 14; N22

4) Responding to emergencies and/or problems with common sense, and a willingness to make the hard decisions

P12) Is a problem solver who uses common sense (4)

P13) Responds appropriately in emergencies and makes the hard [problem solving] decisions (4)

UKA: P8) Gives feedback and constructive criticism to his/her people; P32) Actively monitors individual and team performance; $\underline{\mathrm{P}} 3$

UKB: P12) Takes control of difficult situations and deals with them quickly and appropriately.

UKD: P10. Proactively addresses poor performance issues with staff; P25
UKA: P38; $\underline{P}$

UKB: P3) When faced with urgent or difficult problems/situations is good at making decisions and following them through and keeping promise;.P6, P12, P13.

UKC: P16; P25.

UKD: $\mathrm{P} 11 ; \mathrm{P} 1, \mathrm{P} 17$ 


\section{PERCEIVED MANAGERIAL AND LEADERSHIP EFFECTIVENESS}

\begin{tabular}{|c|c|}
\hline \multicolumn{2}{|l|}{$\begin{array}{l}\text { 5) Investigating /handling difficult work situation in a non- } \\
\text { threatening way and sensitive personal issues with } \\
\text { discretion }\end{array}$} \\
\hline $\begin{array}{l}\text { P14) Handles conflict, discipline and personal issues with } \\
\text { discretion (2) } \\
\text { P15) Conducts non-threatening investigations and with blunt } \\
\text { honest communication and direction (2) }\end{array}$ & $\begin{array}{l}\text { UKB: P11) Deals with difficult and personal issues with } \\
\text { sensitivity (e.g. disciplinary or emotive situations). } \\
\text { UKC: P7) }\end{array}$ \\
\hline \multicolumn{2}{|l|}{$\begin{array}{l}\text { 6) Showing personal interest in the work of employees, } \\
\text { interacting with them, and promoting/publicizing their } \\
\text { activities/achievements }\end{array}$} \\
\hline $\begin{array}{l}\text { P16) Working side by side with employees (2) } \\
\text { P17) Displays high levels of interest in the employee's job (2) }\end{array}$ & $\begin{array}{l}\text { UKB: P10) Promotes the importance and needs of his/her own } \\
\text { department. P9; P19. }\end{array}$ \\
\hline $\begin{array}{l}\text { P18) Promoting [publicizing/parading] group activities } \\
\text { [and group achievements] (2) } \\
\text { Near Opposite Negative BS } \\
\text { N33) Does not engage in the work or workgroup }\end{array}$ & $\begin{array}{l}\text { UKC: P6. Assists other staff at busy times (e.g. is prepared to get } \\
\text { 'stuck in' to alleviate work overloads); P20. Makes time to talk to } \\
\text { staff (e.g. engenders a feeling of value in staff by showing an interest in } \\
\text { their work).; } \underline{\mathrm{P} 19} ; \mathrm{P} 4\end{array}$ \\
\hline \multicolumn{2}{|l|}{$\begin{array}{l}\text { 7) Showing recognition and appreciation of staff who work } \\
\text { well by praising and thanking them }\end{array}$} \\
\hline $\begin{array}{l}\text { P19) Recognizes people and effort showing appreciation and } \\
\text { saying thank you (4) } \\
\text { P20) Gives praise for work well done, recognizing employees } \\
\text { and their service (4) } \\
\text { Near Opposite Negative BS } \\
\text { N42) Does not show appreciation or give praise for work well } \\
\text { done. }\end{array}$ & $\begin{array}{l}\text { UKA: P10; N38; } N 32 . \\
\text { UKB: P26. } \\
\text { UKC: P1; } N 7 \\
\text { UKD: P3) Praises staff regularly on achievements, shows } \\
\text { appreciation and says 'thank you'; N17 }\end{array}$ \\
\hline \multicolumn{2}{|l|}{$\begin{array}{l}\text { 8) Delegating to staff degrees of autonomy and } \\
\text { empowering them }\end{array}$} \\
\hline $\begin{array}{l}\text { P21) Is willing to share power (0) } \\
\text { P22) Delegates (3) } \\
\text { P23) Allows employees some autonomy, doesn't interfere (4) } \\
\text { P24) Empowers employees (4) } \\
\text { Near Opposite Negative BS } \\
\text { N48) Displays poor delegation. }\end{array}$ & $\begin{array}{l}\text { UKA: P23) Empowers people (e.g. encourages staff to take on } \\
\text { responsibility normally above their grade; allows people to set up/run } \\
\text { projects; fosters a higher involvement across grades in decision- } \\
\text { making); P15, P26. } \\
\text { UKB: P1; P7; P18 } \\
\text { UKC: P17) Positively delegates work to staff (e.g. is fair in } \\
\text { delegating work, not just the 'dirty' work); P24 } \\
\text { UKD: P14; P19; P21; N2; N20 }\end{array}$ \\
\hline \multicolumn{2}{|l|}{$\begin{array}{l}\text { 9) Showing genuine concern for employees' welfare and/or } \\
\text { well-being }\end{array}$} \\
\hline $\begin{array}{l}\text { P25) Cares for people showing genuine concern for employee, } \\
\text { their safety, and family [well-being] (3) }\end{array}$ & $\begin{array}{l}\text { UKA: P24) Shows an interest in and listens to the concerns and } \\
\text { anxieties of staff and takes positive action to address the } \\
\text { problem; P6 } \\
\text { UKC: P14; P3 } \\
\text { UKD: P20; P4. }\end{array}$ \\
\hline \multicolumn{2}{|l|}{$\begin{array}{l}\text { 10) Actively supporting the learning and development of } \\
\text { staff through mentoring. coaching, training and/or by } \\
\text { challenging them }\end{array}$} \\
\hline $\begin{array}{l}\text { P26) Displays the ability to mentor and coach by setting the } \\
\text { example (3) } \\
\text { P27) Enabler providing the right tools, training and resources } \\
\text { (4) } \\
\text { P28) Supporting employees in [development] opportunities } \\
\text { (4) } \\
\text { P29) Challenging the employees [as part of their personal } \\
\text { development] (0) } \\
\text { Near Opposite Negative BS } \\
\text { N41) Provides limited opportunities for[personal] growth, } \\
\text { N43) Does not provide guidance or training to new } \\
\text { employees, } \\
\text { N44) Does not provide opportunities to those employees who } \\
\text { wanted to grow. }\end{array}$ & 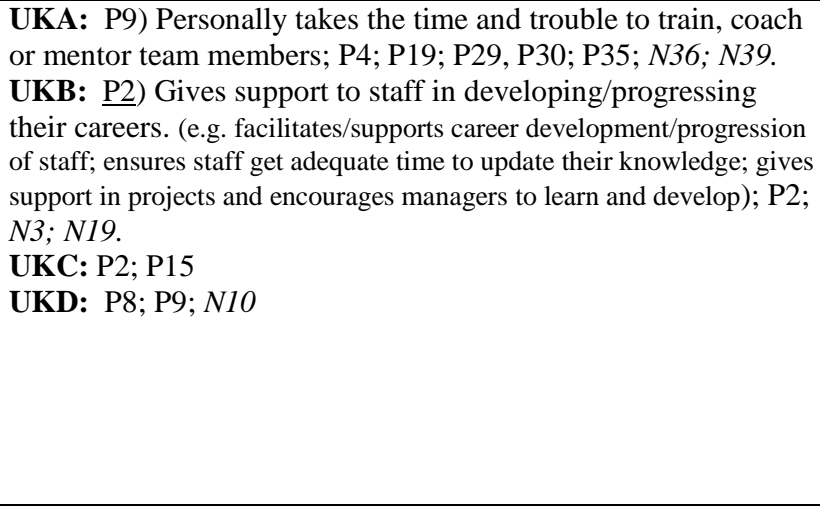 \\
\hline
\end{tabular}




\section{PERCEIVED MANAGERIAL AND LEADERSHIP EFFECTIVENESS}

\begin{tabular}{|c|c|}
\hline \multicolumn{2}{|l|}{$\begin{array}{l}\text { 11) Building and leading a team by adopting a personal } \\
\text { approach and developing trusting and respectful } \\
\text { relationships }\end{array}$} \\
\hline $\begin{array}{l}\text { P30) Builds personal and team relationships by interacting } \\
\text { with employees (3) } \\
\text { P31) Demonstrates integrity and openness (2) } \\
\text { P32) Is humble (0) } \\
\text { P33) Shows trust and respect (2) } \\
\text { P34) Is genuine and approachable (2) }\end{array}$ & $\begin{array}{l}\text { UKA: P33) Proactively sets out to build the team (e.g. ensures } \\
\text { right people in right roles; gets to know people on 1-to-1 basis; } \\
\text { inculcates team working; organizes team building events) } \\
\text { UKB: } \mathrm{P} 9 ; \text {; } 30 \\
\text { UKC: P11) Uses a personal approach to leadership (e.g. } \\
\text { develops a sense of trust); P13. }\end{array}$ \\
\hline \multicolumn{2}{|l|}{$\begin{array}{l}\text { 12) Following through on promises, commitments and } \\
\text { agreements) }\end{array}$} \\
\hline $\begin{array}{l}\text { P35) Follows through on promises and commitments (1) } \\
\text { Near Opposite Negative BS } \\
\text { N39) Does not follow through on earlier agreements }\end{array}$ & $\begin{array}{l}\text { UKB: P3) When faced with urgent or difficult problems/ } \\
\text { situations is good at making decisions and following them } \\
\text { through and keeping promises; } N 36\end{array}$ \\
\hline \multicolumn{2}{|l|}{$\begin{array}{l}\text { 13) Involving staff in decisions by listening to their ideas } \\
\text { and concerns, asking for input, and drawing out } \\
\text { information }\end{array}$} \\
\hline $\begin{array}{l}\text { P36) Listening to ideas and concerns (4) } \\
\text { P37) Asking for input (4) } \\
\text { P38) Draws information out of staff (4) } \\
\text { P39) Involves people [in decisions], (4) } \\
\text { Near Opposite Negative BS } \\
\text { N40) Discounts employee ideas. }\end{array}$ & $\begin{array}{l}\text { UKA: P34) Involves team members in the processes of } \\
\text { decision-making and problem solving, and actively seeks their } \\
\text { ideas and suggestions; P5; } N 3 \text {. } \\
\text { UKB: P4; P8; P16; P24; P27; N7 } \\
\text { UKC: P21) When making decisions, gathers the facts and } \\
\text { considers the views from other members of staff; P18 } \\
\text { UKD: P6; P7; P18; N2 }\end{array}$ \\
\hline \multicolumn{2}{|l|}{$\begin{array}{l}\text { 14) Engaging in effective two-way communications and } \\
\text { holding regular meetings with staff }\end{array}$} \\
\hline $\begin{array}{l}\text { P40 Communicates in two-way dialogue (1) } \\
\text { P41 Keeps the team focused through communication (2) } \\
\text { P42 Displays effective work management through holding } \\
\text { effective meetings (4) }\end{array}$ & $\begin{array}{l}\text { UKA: P21) Promotes and fosters good communications with } \\
\text { people (e.g. team briefings; relaying information; helping staff to } \\
\text { assimilate dry/complex information); P7; P13; P39. } \\
\text { UKB: P 22) Holds regular meetings and/or team briefings with } \\
\text { his/her team. } \\
\text { UKC: P5. } \\
\text { UKD: P23. }\end{array}$ \\
\hline \multicolumn{2}{|l|}{$\begin{array}{l}\text { 15) Sharing important information with staff on matters } \\
\text { they need to know about }\end{array}$} \\
\hline $\begin{array}{l}\text { P43 Providing information employees need to know (4) } \\
\text { P44 Is willing to share information (4) }\end{array}$ & $\begin{array}{l}\text { UKA: P39; P42. } \\
\text { UKB: P23) Keeping staff and colleagues regularly informed } \\
\text { and up to date on what is happening and on matters directly } \\
\text { affecting them. } \\
\text { UKC: P8. } \\
\text { UKD: P15. }\end{array}$ \\
\hline $\begin{array}{l}\text { 16) Showing and securing commitment for change } \\
\text { initiatives, acting as change champion and taking } \\
\text { ownership of the change process }\end{array}$ & : \\
\hline $\begin{array}{l}\text { P45) Displays commitment to change acting as the champion } \\
\text { (2) } \\
\text { P46) Walking the talk [on change initiatives], setting the } \\
\text { example, engaging employees by telling the story, providing } \\
\text { the context to change (2) } \\
\text { P47) Takes control and ownership over the change process (0) } \\
\text { Near Opposite Negative BSs } \\
\text { N35) Displays poor vision } \\
\text { N36) Displays poor change management [skills], } \\
\text { N37) Displays resistance [to change] and rigidity in his/her } \\
\text { thinking } \\
\text { N38) Does not champion or communicate the ideas [for } \\
\text { change] with the staff, }\end{array}$ & $\begin{array}{l}\text { UKA: P37) Innovates change or takes the initiative to offer } \\
\text { improvement for the benefit of staff and organization; P7; P14; } \\
N 7 ; N 26 ; N 37 \\
\text { UKB: P25) In change situations he/she proactively canvasses } \\
\text { and listens to the opinions of his/her staff, seeks their } \\
\text { ideas/suggestions and invites them to voice any concerns or } \\
\text { fears they may have; } \underline{\mathrm{P} 24} ; N 25 \text {. } \\
\text { UKC: } N 16 . \\
\text { UKD: } \mathrm{P} 15 ; N 23\end{array}$ \\
\hline
\end{tabular}




\section{PERCEIVED MANAGERIAL AND LEADERSHIP EFFECTIVENESS}

\section{Dissimilar positive Canadian BSs but near opposite in Non-convergent positive British BSs}

meaning to one or more negative Canadian BSs

P48) Is decisive [N25 Appears fearful, is indecisive(3)] P49) Holds himself accountable [N26 Does not deal with UKA: P11; P17; P31; P40; P41 (own) accountability issues(3)]

P50) Displays a high level of job knowledge [and] technical expertise [N32 Displays a lack of job/task knowledge(1)]

Note: The brackets at the end of each Canadian BS indicates the number of UK studies where there are convergent British BSs

Note: The underlined 'P' numbers indicate convergent meaning with more than one Canadian BS 


\section{PERCEIVED MANAGERIAL AND LEADERSHIP EFFECTIVENESS}

Table 5.

Deduced Negative Canadian Public Utility BCs with Underpinning BSs and Comparison Against Convergent British Public Sector Negative BSs

\begin{tabular}{|c|c|}
\hline $\begin{array}{c}\text { Canadian Public Utility Study } \\
\text { Deduced Negative Behavioral Criteria } \\
\text { Underpinning negative BSs } \\
\text { Polar opposite positive BSs }\end{array}$ & $\begin{array}{l}\text { British Public Sector Studies } \\
\text { UKA: HM Customs \& Excise -Anglia Region ( } \mathrm{n}=40 \mathrm{BSs}) \\
\text { UKB: An Acute NHS Trust Hospital ( } \mathrm{n}=37 \mathrm{BSs}) \\
\text { UKC: Birmingham Women's NHS Trust Hospital }(\mathrm{n}=24 \mathrm{BSs}) \\
\text { UKD: W'ton City Council Social Services Dept. ( } \mathrm{n}=25 \mathrm{BSs}) \\
\text { Convergent negative BSs } \\
\end{array}$ \\
\hline \multicolumn{2}{|l|}{ 1) Inappropriate autocratic controlling behavior } \\
\hline $\begin{array}{l}\text { N1) Pushes the staff to conform rather than gaining buy- } \\
\text { in. } \\
\text { N2) Displays authoritarian and controlling behaviours (2). } \\
\text { N3) Barking commands (2) } \\
\text { N4) Micromanages employees work and time (0) } \\
\text { N5) Questions every decision [made by staff] (0) }\end{array}$ & $\begin{array}{l}\text { UKA: N4; N14; N18. } \\
\text { UKB: N8; N9; N24; N28. }\end{array}$ \\
\hline \multicolumn{2}{|l|}{ 2) Exhibiting selfish and/or self-serving behavior } \\
\hline $\begin{array}{l}\text { N6) Expecting people to drop everything they are doing to } \\
\text { attend to his/her requests (1) } \\
\text { N7) Blaming employees [for own mistakes] (4) } \\
\text { N8) Spreads the blame (3) }\end{array}$ & $\begin{array}{l}\text { UKA: N2 } \\
\text { UKB: N12. } \\
\text { UKC: N3; N20. } \\
\text { UKD: N7; N9 }\end{array}$ \\
\hline \multicolumn{2}{|l|}{$\begin{array}{l}\text { 3) Behaving in ways that mislead and/or manipulate } \\
\text { people }\end{array}$} \\
\hline $\begin{array}{l}\text { N9) Provides insincere praise (1) } \\
\text { N10) Provides unclear, negative, biased or misleading } \\
\text { one-way communication (3) } \\
\text { N11) Exhibits double standards (0) } \\
\text { N12) [In conflict situations] paints everyone with the } \\
\text { same brush, and sends mixed messages to those involved } \\
\text { in the conflict (1) } \\
\text { N15) Engages in questionable hiring practicing (1) }\end{array}$ & $\begin{array}{l}\text { UKA: N34 } \\
\text { UKB: N17; N23. } \\
\text { UKC: N21 } \\
\text { UKD: } \underline{\text { N5 }}\end{array}$ \\
\hline \multicolumn{2}{|l|}{ 4) Treating staff inconsistently and/or with favoritism } \\
\hline $\begin{array}{l}\text { N13) Treated people inconsistently (4) } \\
\text { N14) Displays unprofessionalism showing favoritism (2) }\end{array}$ & $\begin{array}{l}\text { UKA: N10; N22 } \\
\text { UKB: N35. } \\
\text { UKC: N1. } \\
\text { UKD: N24. }\end{array}$ \\
\hline \multicolumn{2}{|l|}{$\begin{array}{l}\text { 5) Taking the credit/praise for the efforts/ideas of } \\
\text { others }\end{array}$} \\
\hline $\begin{array}{l}\text { N16) Takes the praise for themselves (1) } \\
\text { N17) Takes credit for other's ideas (1) }\end{array}$ & UKA: N30 \\
\hline \multicolumn{2}{|l|}{$\begin{array}{l}\text { 6) Exhibiting rude, disrespectful, undermining and/or } \\
\text { intimidating/bullying behaviour (4) }\end{array}$} \\
\hline $\begin{array}{l}\text { N18) Is rude and disrespectful [ to staff] (4) } \\
\text { N19) Is intimidating and emotional (4) } \\
\text { N20) Yelling, threatening, screaming, interrupting, and } \\
\text { bullying the staff (4) } \\
\text { N21) Ignores privacy and confidentiality rules (3) }\end{array}$ & $\begin{array}{l}\text { UKA: N1; N9; N24 } \\
\text { UKB: N10; N11; N18; N20; N21 } \\
\text { UKC: N4; N10;N11; N24 } \\
\text { UKD: } \mathrm{N} 5 ; \mathrm{N} 11 ; \mathrm{N} 15 ; \mathrm{N} 18 ; \mathrm{N} 19\end{array}$ \\
\hline \multicolumn{2}{|l|}{$\begin{array}{l}\text { 7) Avoiding dealing with conflict and/or disciplinary } \\
\text { issues }\end{array}$} \\
\hline $\begin{array}{l}\text { N22) Avoids dealing with conflict (4) } \\
\text { N23) Does not discipline but becomes angry or } \\
\text { confrontational (3) }\end{array}$ & $\begin{array}{l}\text { UKA: N8; N19; N20; N28. } \\
\text { UKB: N4; N13 } \\
\text { UKC: N17 } \\
\text { UKD: N1; N4; N8 }\end{array}$ \\
\hline \multicolumn{2}{|l|}{ 8) Procrastinates and/or avoids making decisions } \\
\hline $\begin{array}{l}\text { N24) Displays hesitancy about making decisions (3) } \\
\text { N25) Appears fearful, is indecisive (3) } \\
\text { Near Opposite Positive BS }\end{array}$ & $\begin{array}{l}\text { UKA: N15. } \\
\text { UKB: N4. } \\
\text { UKC: N12. }\end{array}$ \\
\hline
\end{tabular}




\section{PERCEIVED MANAGERIAL AND LEADERSHIP EFFECTIVENESS}

\begin{tabular}{ll}
\hline P48 Is decisive & \\
$\begin{array}{ll}\text { 9) Abdicates from responsibilities and accountability } \\
\text { (3) }\end{array}$ \\
$\begin{array}{ll}\text { N26) Does not deal with [own] accountability issues (3) } & \text { UKA: N33. } \\
\text { Near Opposite Positive BS } & \text { UKB: N2. } \\
\text { P49 Holds himself accountable } & \text { UKD: N6; N8; N13. }\end{array}$
\end{tabular}

10) Making decisions based on emotion and/or on assumptions without adequate investigation of the facts

N27) When he does discipline he does not fully consider the ramifications of the conflict solution or does not fully investigate (2)

N28) Makes [decisions on] assumptions (2)

N29) Reacts emotionally rather than rationally (3)

11) Avoiding interaction with staff and/or not being available for direct communication with them

N30) Was not available (1)

N31) Did not interact or communicate with staff (3)

UKA: N6; N11

UKB: N37.

12) Displays a lack of job knowledge and/or departmental expertise

N32) Displays a lack of job/task knowledge (1).

UKA: N25.

UKB: N1; N6

UKD: N13.

Near Opposite Positive BS

P50) Displays a high level of job knowledge, technical

expertise

Dissimilar negative Canadian BSs but near opposite in meaning to one or more positive Canadian BSs

N33) Does not engage (absence of leader) in the work or workgroup

N34) Provides no support with other groups

N35) Displays poor vision and change management

UKD: N3

N36) Displays poor change management [skills]

N37) Displays resistance and rigidity in his/her thinking

N38) Does not champion or communicate his ideas with the staff

N39) Does not follow through on earlier agreements

N40) Discounts employees' ideas

N41) Provides limited opportunities for [personal] growth

N42) Does not show appreciation or give praise for work well done

N43) Does not provide guidance or training for new employees

N44) Does not provide opportunities to those employees who wanted to grow

N45) Does not plan, schedule or prioritize well

N46) Fire fights rather than plan for the future

N47) Displays poor organization [and] focus

N48) Displays poor delegation

N49) Provides no structure or expectations

Note: The brackets at the end of each Canadian BS indicates the number of UK studies where there are convergent British BSs

UKB: N5.

Non-convergent negative British BSs

UKA: N5; N12; N13; N24; N25; N29; N31; N35; N39; N40

UKB: Nil

UKC: N3; N4; N15; N18; N20; N21; N22; N23

UKD: N5; N16; N21; N23.

Note: The underlined ' $\mathrm{N}$ ' numbers indicate convergent meaning with more than one Canadian BS 
Table 6.

Illustration of Convergence Between the Constituent BSs of Two Canadian BCs and the Compared British BSs

\begin{tabular}{|c|c|}
\hline Canadian Public Utility Study & $\begin{array}{l}\text { British Public Sector Studies } \\
\text { UKA: HM Customs \& Excise -Anglia Region } \\
\text { UKB: An Acute NHS Trust Hospital } \\
\text { UKC: Birmingham Women's NHS Trust Hospital } \\
\text { UKD: Wolverhampton City Council Social Services Department }\end{array}$ \\
\hline $\begin{array}{l}\text { Positive Behavioral Criterion No. } 7 \\
\text { Showing recognition and appreciation of } \\
\text { staff who work well by praising and } \\
\text { thanking them }\end{array}$ & Convergent positive BSs and polar opposite negative BSs \\
\hline $\begin{array}{l}\text { P19) Recognizes people and effort showing } \\
\text { appreciation and saying thank you (4) } \\
\text { P20) Gives praise for work well done, } \\
\text { recognizing employees and their service (4) } \\
\text { Near Opposite Negative BS } \\
\text { N39) Does not show appreciation or give } \\
\text { praise for work well done. }\end{array}$ & $\begin{array}{l}\text { UKA: P10) Gives recognition, appreciation or praise when due to } \\
\text { team members } \\
\quad \text { N32) Refuses to nominate people for special bonus awards or to } \\
\text { give rewards } \\
\text { N38) Fails to give recognition or acknowledgement for the good } \\
\text { work of others } \\
\text { UKB: P26) Thanks people and gives praise for a job well done. (e.g. } \\
\text { makes the effort to thank the individual and/or the team). } \\
\text { UKC: P1) Values the work of his/her team and acknowledges work } \\
\text { completed to a high standard } \\
\quad \text { N7 Does not praise or give credit when it is due. } \\
\text { UKD: P3). Praises staff regularly on achievements, shows } \\
\text { appreciation and says 'thank you' } \\
\text { N17. Shows lack of appreciation for staff's efforts }\end{array}$ \\
\hline $\begin{array}{l}\text { Negative Behavioral Criterion No. } 4 \\
\text { Treating staff inconsistently and/or with } \\
\text { favoritism }\end{array}$ & Convergent negative BSs \\
\hline $\begin{array}{l}\text { N13) Treated people inconsistently (4) } \\
\text { N14) Displays unprofessionalism showing } \\
\text { favoritism (2) }\end{array}$ & $\begin{array}{l}\text { UKA: N10) Shows favoritism when allocating resources such as office } \\
\text { accommodation, furniture, IT equipment; N22) Within the promotional } \\
\text { system exhibits favouritism } \\
\text { UKB: N35) Is inconsistent and/unfair in his dealings or handling of } \\
\text { people } \\
\text { UKC: N1) Does not treat staff equally (e.g. unfairly praises staff when not } \\
\text { deserved) } \\
\text { UKD: N24) Shows favoritism }\end{array}$ \\
\hline
\end{tabular}

